\title{
Design, Synthesis and Characterization of Novel Sulfonamides Derivatives as Anticancer Agent Targeting EGFR TK, and Development of New Methods of Synthesis by Microwave Irradiation
}

\author{
Souad Akili', Djamila Ben Hadda², Yaser Bitar ${ }^{1}$, Amir Balash ${ }^{3}$, Mustapha Fawaz Chehna ${ }^{{ }^{*}}$ \\ ${ }^{1}$ Department Quality Control and Pharmaceutical Chemistry, Faculty of Pharmacy, University of Aleppo, Aleppo, Syria \\ ${ }^{2}$ Department Quality Control and Pharmaceutical Chemistry, Faculty of Pharmacy, Ebla Private University, Aleppo, Syria \\ ${ }^{3}$ Department of Pharmaceutical Chemistry, Institute of Pharmacy, University of Marburg, Marburg, Germany \\ Email: *mf.chehna@gmail.com
}

How to cite this paper: Akili, S., Hadda, D. B., Bitar, Y., Balash, A., \& Chehna, M. F. (2021) Design, Synthesis and Characterization of Novel Sulfonamides Derivatives as Anticancer Agent Targeting EGFR TK, and Development of New Methods of Synthesis by Microwave Irradiation. International Journal of Organic Chemistry, 11, 199-223. https://doi.org/10.4236/ijoc.2021.114014

Received: September 22, 2021

Accepted: December 5, 2021

Published: December 8, 2021

Copyright $\odot 2021$ by author(s) and Scientific Research Publishing Inc. This work is licensed under the Creative Commons Attribution International License (CC BY 4.0).

http://creativecommons.org/licenses/by/4.0/ (c) (i) Open Access

\begin{abstract}
Some novel sulfonamide-derivatives were designed to develop novel kinase inhibitors. The molecular docking study was performed for the designed compounds against epidermal growth factor kinase receptor T790M/L858R (TMLR) (PDB ID: 5EDQ) to identify new drug candidates for treating cancer. Binding free energy was calculated by Molegro virtual docker (MVD) to select the most promising hits. The corresponding docking score values into EGFR (TMLR) of $4 \mathrm{~b}$ gave the best energy docking $-147.213 \mathrm{Kcal} / \mathrm{mol}$. And some of the designed sulfonamide derivatives have been synthesized by conventional method in addition to a microwave-assisted method of synthesis. The reaction of an amino group-containing drug; sulfamethoxazole and sulfanilamide with carbonyl group in benzoyl chloride and phthalic acid in basic media, generated a series of sulfonamide derivatives. The structures of all the synthesized compounds were well characterized by Mass spectrometry (MS), Infrared spectroscopy (IR), ${ }^{1} \mathrm{H}$ nuclear magnetic resonance $\left({ }^{1} \mathrm{H} \mathrm{NMR}\right),{ }^{13} \mathrm{C}$ nuclear magnetic resonance $\left({ }^{13} \mathrm{C} \mathrm{NMR}\right)$ and elemental analysis. After obtaining experimental data regarding the yield and the time taken for the synthesis by both the approaches, conventional and microwave-assisted method, it was shown that the microwave-assisted method gave higher yield with shorter time and higher temperature compared to conventional heating methods.
\end{abstract}

\section{Keywords}

Sulfonamide, Anticancer, EGFR, TMLR, 5EDQ, Molegro Virtual Docker, Sulfamethoxazole, Sulfanilamide, Microwave 


\section{Introduction}

Cancer is a worldwide health problem and the most deadly disease in humans [1] [2], and it is considered the second leading cause of mortality after cardiovascular diseases [2]. There are several methods for the treatment of cancer such as Surgery, Chemotherapy, Hormonal therapy, Immunotherapy [3] [4], and Phototherapy [5]. Today, anticancer chemotherapy is still the main method applied in the treatment of cancer [6]. Chemotherapy drugs include antitumor antibiotics, anti-metabolites, mitotic inhibitors, hormonal therapies. Cancer chemotherapy offers a unique advantage: it can treat the entire body, even the cells that may have escaped from the primary tumor [4] [7].

Among the wide range of compounds tested as potential anticancer agents, derivatives of sulfonamide have attracted reasonable attention [8].

The compounds which contain $\mathrm{SO}_{2} \mathrm{NH}_{2}$ functional group are called sulfonamides. The general formula of sulfonamides is $\mathrm{RSO}_{2} \mathrm{NH}_{2}$ [9] (Figure 1).

Sulfa drugs are amphoteric, they have pKa 4.79 to 8.56 and act as weak organic acids. They are weakly soluble in water, their solubility is increased at alkaline $\mathrm{pH}$. The lipophilicity of the $\mathrm{N}_{1}$ group has the largest effect on protein binding [10]. Sulfonamide derivatives comprise an important class of drugs with diverse biological applications [11]. Over 30 drugs containing this functional group are in clinical use, including antihypertensive, antibacterial, antiprotozoal, antifungal, anti-inflammatory, non-peptidic vasopressin receptor antagonists, translation initiation inhibitors, rheumatoid arthritis, antimalarial, anti-leishmanial, anti-thyroid, Antidepressant [10] [11] [12], hypoglycemics, anticonvulsants [13], diuretic, receptor tyrosine kinase inhibitors, and antipsychotics [1]. They are also used to treat ulcerative colitis, urinary, intestinal, and ophthalmic infections [14]. Recently, sulfonamides have been used as anti-cancer, anti-viral, and anti-HIV [15] [16], and in Alzheimer's disease [13].

Epidermal growth factor receptor (EGFR) is a member of the tyrosine kinase family and is usually overexpressed in several types of cancer, such as non-small-cell lung cancer, breast, esophageal, head, cervical, and neck cancer [17] [18]. The TMLR (T790M/L858R) mutation, the L858R mutation is located in the tyrosine kinase domain of EGFR in exon 2 and deletions within exon 19, and T790M is located in exon 20 of EGFR within the kinase domain where the threonine gatekeeper residue Thr790 is exchanged for methionine T790M [19] [20] [21].

Recently, some sulfonamide derivatives carrying pyrrole and pyrrolopyrimdine cycles have been synthesized by Ghorab et al. in 2014 and have antitumor activity. Most of the synthesized compounds showed good activity as cytotoxic

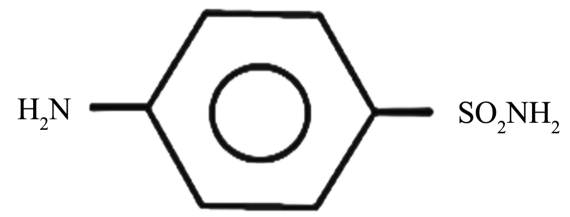

Figure 1. The structure of sulfanilamide. 
agents with better IC50 than doxorubicin as a reference drug. The molecular docking study was performed on the human c-Src for all synthesized compounds [22].

Ihmaid et al. in 2018 designed and synthesized some novel anthranilate sulfonamide derivatives having anticancer activity. The molecular docking study was performed against EGFR [6].

In the past few years, the use of microwave as an energy resource to induce organic reactions has been a useful technique in organic synthesis. Microwave irradiation has been shown to dramatically reduce reaction times, increase product yields and enhance product purities by reducing unwanted side reactions compared to conventional heating methods [23] [24] [25].

Due to our interest in the development of novel anticancer agents, in this study, we report the design and synthesis of some novel sulfonamide derivatives and we expect that these new compounds might show significant anticancer activity.

\section{Materials and Methods}

Protein Data Bank (PDB), PubMed and software like ChemSketch version 14.01, Marvin sketch version 21.2, and Molegro Virtual Docker (MVD) version 2011.4.3 were implemented within the current study.

A Monowave 300 microwave oven was used for microwave synthesis (Anton Paar, Austria) and we used reaction vial G30 equipped with snap caps and silicon septa. Melting points were determined in open capillary on a BÜCHI Melting Point B-540 apparatus (BÜCHI Labortechnik, Switzerland). Analytical thin-layer chromatography (TLC) was performed with silica gel 60 F254 aluminum sheets (Macherey-Nagel, Germany). IR spectra ( $\mathrm{KBr}$ disc) were recorded using an ATR-FTIR Bruker spectrophotometer (Bruker, Billerica, Massachusetts). ${ }^{1} \mathrm{H}-\mathrm{NMR}$ spectra were scanned on JEOL-ECA NMR spectrophotometer (Joel, Tokyo, Japan), operating at $400 \mathrm{MHz}$ for $1 \mathrm{H}$ and 13C. Chemical shifts are expressed in $\delta$-values (ppm), using DMSO-d6 as a solvent. Mass spectra (MS) were scanned by the triple quadrupole mass spectrometer with positive ionization (Sciex, Framingham, USA). The $\mathrm{m} / \mathrm{z}$ values of the more intense peaks are mentioned.

\section{EGFR structure}

The 3D crystal structure of EGFR Kinase T790M/L858R (TMLR) (PDB ID: 5EDQ) domain was retrieved from PDB and has a resolution of $2.8 \AA$. The kinase domain consists of 327 residues between 695 - 1022 residues. The resolved EGFR structure was co-crystallized as holo-form with a known kinase inhibitor ( N-(7-Chloro-1H-indazol-3-yl)-7,7-dimethyl-2-(1H-pyrazol-4-yl) -5H-furo[3,4d] pyrimidin-4-amine) (5N3) (Figure 2).

\section{Define the binding pocket:}

The binding pocket was defined using the co-crystallized ligand as a center of the pocket, which had a volume of $312.32 \AA$, and fitted to the polar surface area for designed compounds (Figure 3). 


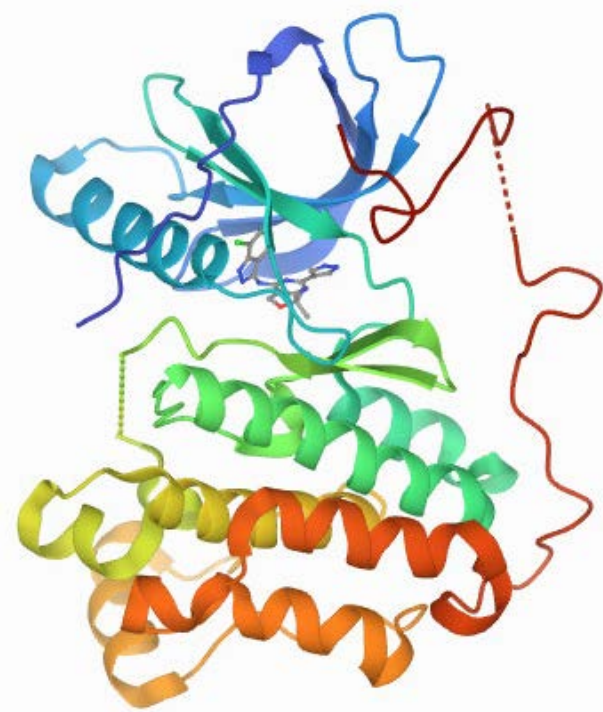

Figure 2. Co-crystal structure of the EGFR TMLR (PDB ID: 5EDQ) kinase domain in complex with $5 \mathrm{~N} 3$.

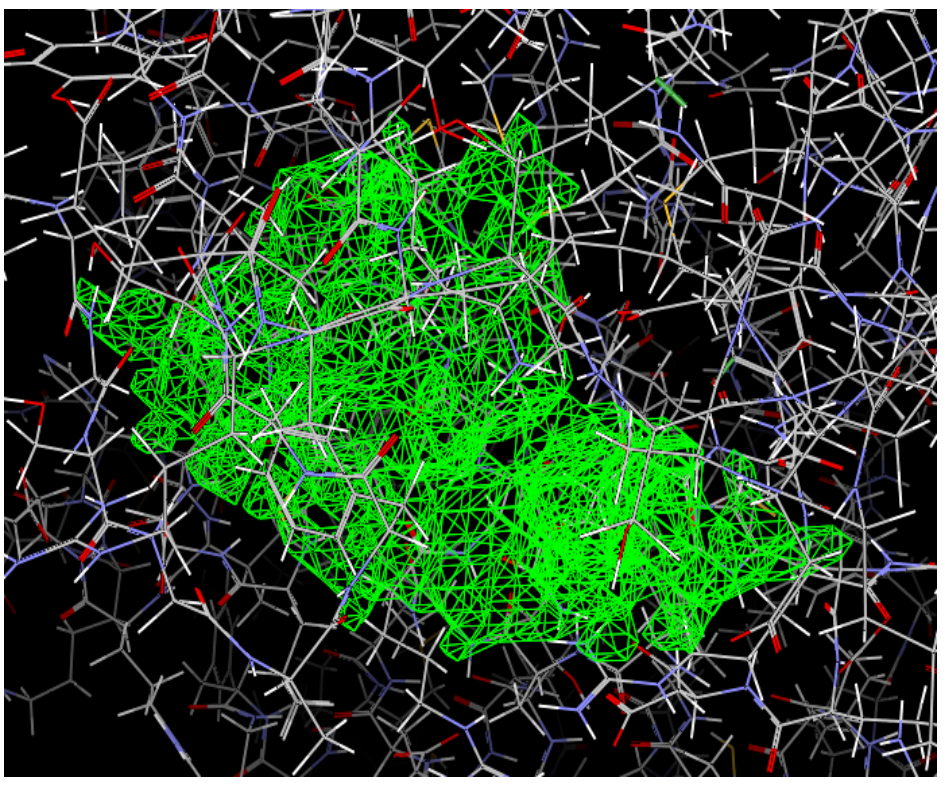

Figure 3. EGFR (TMLR) binding pocket (PDB ID: 5EDQ) used to dock the designed compounds.

\section{Compounds preparation:}

Structures of designed compounds were drawn and optimized by using Marvin Sketch and saved as mol2. The preparation of compounds was performed using the default setting to assign bonds, create explicit hydrogens, assign bond orders and hybridization, assign charges (calculated by MVD), assign tripos atom types, and detect flexible torsions in ligands.

\section{Molecular Docking:}

The Molecular Docking was performed in MVD. The following parameters were used for docking in the EGFR kinase (Table 1). 
Table 1. Parameters of Molegro Virtual Docker.

\begin{tabular}{cc}
\hline Parameters & Value \\
\hline Scoring function & Plants score (GRID) \\
Grid resolution $(\AA)$ & 0.30 \\
Binding site radius $(\AA)$ & 15 \\
Searching algorithm & MolDock SE \\
Number of runs & 10 \\
Max iterations & 1500 \\
Max population size & 50 \\
Energy threshold & 100 \\
Simplex evaluation (max steps) & 300 \\
Neighbor distance factor & 1 \\
\hline
\end{tabular}

The results of docking compounds with the receptors were compared with Osimertinib and Rociletinib which are in use to treat non-small cell lung cancer (NSCLC). Osimertinib docked with EGFR with mutation T790M, L858R, and exon 19 deletions, and Rociletinib docked with EGFR including T790M mutation.

\section{General procedures for the synthesis of compounds:}

\section{- Synthesis of compound $1 \mathrm{~b}$}

Pyridine $(10 \mathrm{ml})$ was placed in a $100 \mathrm{ml}$ round flask fitted with a magnetic stirrer and heated to $70^{\circ} \mathrm{C}$. Sulfamethoxazole $(5 \mathrm{mmol})$ was added to the warmed liquid in several portions, creating a homogeneous yellow solution. The warm solution was stirred while benzoyl chloride $(5 \mathrm{mmol}$ ) was added dropwise. The mixture was stirred for 30 minutes with maintaining the temperature at $70^{\circ} \mathrm{C}$. The mixture was cooled in a cold water bath, then poured into chipped ice to produce a white precipitate, then, filtration, drying at $100^{\circ} \mathrm{C}$ and recrystallizing from ethanol.

\section{- Synthesis of compound 1c}

(11.6 mmol) of sulfanilamide dissolved in $20 \mathrm{ml}$ of $4 \% \mathrm{NaOH}$ and placed in a $100 \mathrm{ml}$ conical flask. Then, $(23.2 \mathrm{mmol})$ of benzoyl chloride was added slowly with vigorous shaking. The flask was closed and shaken for further $30 \mathrm{~min}$ or till the odor of benzoyl chloride can no longer be detected. When the reaction finished, a white precipitate was formed, then, filtration, drying and recrystallizing from hot methanol.

\section{- Synthesis of compound $3 b$}

A mixture of sulfamethoxazole $(8 \mathrm{mmol})$ and triethylamine $(2 \mathrm{ml})$ in dry DMF $(10 \mathrm{~mL})$ were stirred under reflux for $1 \mathrm{~h}$. A solution of phthalic acid (8 $\mathrm{mmol}$ ) was then added dropwise. The reaction mixture was heated under reflux at $200^{\circ} \mathrm{C}$ in oil bath for $3 \mathrm{~h}$. After cooling, the reaction mixture was poured into ice water and the formed solid was collected by filtration and recrystallized from 
acetonitrile.

\section{- Synthesis of compound 3d}

Sulfanilamide (11.6 mmol) and triethylamine $(2 \mathrm{ml})$ in dry DMF $(10 \mathrm{~mL})$ were stirred under reflux for $1 \mathrm{~h}$. Phthalic acid $(11.6 \mathrm{mmol})$ was then added dropwise. The reaction mixture was heated under reflux at $200^{\circ} \mathrm{C}$ in oil bath for $2.5 \mathrm{~h}$. After cooling, the reaction mixture was poured into ice water and the product was collected by filtration and recrystallized from DMF.

\section{Synthesis of compounds by microwave irradiation:}

\section{- Synthesis of compound $1 \mathrm{~b}$}

A mixture of sulfamethoxazole $(5 \mathrm{mmol})$ and benzoyl chloride $(5 \mathrm{mmol})$ was dissolved in $5 \mathrm{ml}$ pyridine and placed in a $30-\mathrm{mL}$ sealed vial. Then, it is put in the microwave and heated to $120^{\circ} \mathrm{C}$, and maintained at this temperature for 10 min. Finally, the reaction was cooled to $55^{\circ} \mathrm{C}$. After completion of the reaction, the mixture of reaction was poured into cold water to produce a white precipitate which was filtered, washed with water and methanol, and dried.

\section{- Synthesis of compound 1c}

$(5.8 \mathrm{mmol})$ of sulfanilamide dissolved in $5 \mathrm{ml}$ pyridine and placed in a $30-\mathrm{mL}$ sealed vial, then, $(11.6 \mathrm{mmol})$ of benzoyl chloride was added and put in the microwave, then, was heated to $100^{\circ} \mathrm{C}$ and was maintained at this temperature for 5 $\min$. Then, the reaction was cooled to $55^{\circ} \mathrm{C}$. When the reaction finished, a white precipitate was formed, which was filtered, washed with water and methanol, and dried.

\section{- Synthesis of compound $3 b$}

Sulfamethoxazole $(4 \mathrm{mmol})$ and phthalic acid $(4 \mathrm{mmol})$ were dissolved in $5 \mathrm{ml}$ pyridine and placed in a $30-\mathrm{mL}$ sealed vial. The reaction mixture was heated to $200^{\circ} \mathrm{C}$ and was kept at this temperature for $20 \mathrm{~min}$. Then, the reaction was cooled to $55^{\circ} \mathrm{C}$. After cooling, the reaction mixture was poured into ice water and the formed solid was collected by filtration, washing with water and methanol, and drying.

\section{- Synthesis of compound 3d}

A mixture of Sulfanilamide $(5.8 \mathrm{mmol})$ and phthalic acid $(5.8 \mathrm{mmol})$ was dissolved in $10 \mathrm{ml}$ pyridine and placed in a $30-\mathrm{mL}$ sealed vial. The reaction mixture was heated to $200^{\circ} \mathrm{C}$ and was kept at this temperature for $20 \mathrm{~min}$. Then, the reaction was cooled to $55^{\circ} \mathrm{C}$. After cooling, a white precipitate was formed which was filtered, washed with water and methanol, and dried.

\section{Results and Discussion}

\section{Sulfonamide derivatives}

The core scaffold of the sulfonamide shown in (Figure 4) was used to design several derivatives in the current study. The structure of designed sulfonamide derivatives is shown in (Table 2).

\section{Molecular Docking results}

The list of compounds was docked into the EGFR (TMLR) receptor binding pocket using the validated docking methods. Docking results tabulated between 
Table 2. Structure of sulfonamide derivatives considered in the study.

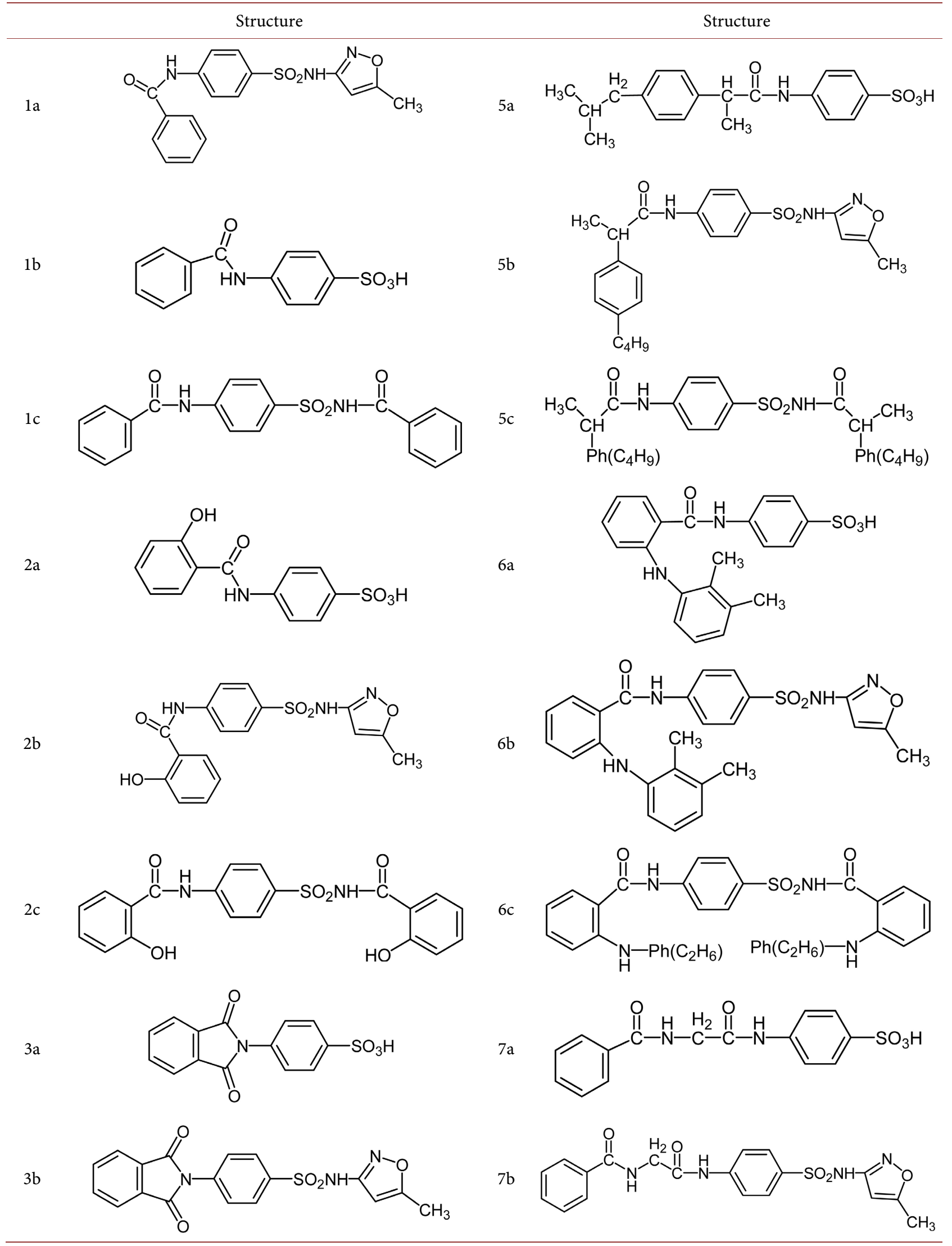




\section{Continued}

$3 c$<smiles>O=C1c2ccccc2C(=O)N1c1ccc(S(=O)(=O)N2C(=O)c3ccccc3C2=O)cc1</smiles>

$3 d$<smiles>NS(=O)(=O)c1ccc(N2C(=O)c3ccccc3C2=O)cc1</smiles>

$4 \mathrm{a}$<smiles>O=C(Cc1ccccc1Nc1c(Cl)cccc1Cl)Nc1ccc(S(=O)(=O)O)cc1</smiles>

$4 \mathrm{~b}$<smiles>Cc1cc(NS(=O)(=O)c2ccc(NC(=O)c3ccccc3Nc3c(Cl)cccc3Cl)cc2)no1</smiles>

$4 c$<smiles>O=C(Cc1ccccc1Nc1ccccc1)NS(=O)(=O)c1ccc(NPc2ccccc2)cc1</smiles>

$7 c$<smiles>O=C(CNC(=O)c1ccccc1)Nc1ccc(S(=O)(=O)NC(=O)CNC(=O)c2ccccc2)cc1</smiles>

$8 a$<smiles>COC(=O)c1ccccc1C(=O)Nc1ccc(S(=O)(=O)O)cc1</smiles>

$8 \mathrm{~b}$<smiles>COC(=O)c1ccccc1CNc1ccc(S(=O)(=O)Nc2cc(C)on2)cc1</smiles>

$8 c$<smiles>COC(=O)c1ccccc1C(=O)Nc1ccc(S(N)(=O)=O)cc1</smiles><smiles>[R2]c1ccc(S([R])(=O)=O)cc1</smiles>

Figure 4. Scaffold of sulfonamide.

the EGFR (TMLR) binding pocket and the derivatives of sulfonamide are shown (Table 3).

\section{Validation docking method}

Validation of docking was used to ensure the orientation and position of ligand binding obtained from docking studies by MVD program. Therefore, the parameters must be validated by re-dock the native ligand into the crystal structure (PDB ID: 5EDQ). After that, it was extracted and re-docked into the binding pocket to generate the X-ray binding mode. The ability of the docking algorithm to generate the active biding mode of the ligands was evaluated by 
Table 3. The energy docking of ligands with receptors.

\begin{tabular}{|c|c|}
\hline Ligand & Energy docking with $2 \mathrm{ITY}(\mathrm{Kcal} / \mathrm{mol})$ \\
\hline $4 \mathrm{~b}$ & -147.213 \\
\hline $5 \mathrm{~N} 3$ & -140.856 \\
\hline $6 c$ & -132.14 \\
\hline $5 b$ & -129.55 \\
\hline $4 c$ & -118.092 \\
\hline Osimertinib & -115.633 \\
\hline $5 c$ & -113.682 \\
\hline $6 b$ & -112.186 \\
\hline $3 b$ & -111.724 \\
\hline $7 \mathrm{~b}$ & -108.864 \\
\hline $6 a$ & -106.005 \\
\hline Rociletinib & -104.706 \\
\hline $4 \mathrm{a}$ & -104.538 \\
\hline $2 \mathrm{~b}$ & -101.977 \\
\hline $3 c$ & -95.6706 \\
\hline $3 a$ & -91.0155 \\
\hline $2 c$ & -90.485 \\
\hline $1 b$ & -90.3229 \\
\hline $5 \mathrm{a}$ & -88.3473 \\
\hline $8 b$ & -88.1895 \\
\hline $3 \mathrm{~d}$ & -86.0797 \\
\hline $1 \mathrm{c}$ & -84.7441 \\
\hline $7 \mathrm{c}$ & -83.6132 \\
\hline $8 \mathrm{a}$ & -81.1525 \\
\hline $2 \mathrm{a}$ & -80.798 \\
\hline $7 \mathrm{a}$ & -78.8822 \\
\hline $1 \mathrm{a}$ & -73.2927 \\
\hline $8 c$ & -70.8233 \\
\hline
\end{tabular}

calculating the RMSD (Root Mean Square Deviation) between the docking solutions and the X-ray binding mode. RMSD $<2 \AA$ considered as a threshold in the computer-aided drug design.

The RMSD value for the top-ranked docking solution of ligand was 0.565382 . Thus, the applied docking methods were able to generate the $\mathrm{X}$-ray binding mode of the ligand. 
The interactions between the binding pocket residues of the EGFR (TMLR) receptor and the sulfonamide derivatives together with energy docking are shown in Table 4.

\section{Synthesis of compounds}

\section{- Mechanism of synthesis}

\section{Compound $1 \mathrm{~b}$}

The reaction of sulfamethoxazole (1) with benzoyl chloride (2) in pyridine with refluxing, results in the desired $N$-\{4-[(5-methyl-1,2-oxazol-3-yl)sulfamoyl] phenyl\}benzamide (1b) in $84 \%$ yield, and in $89 \%$ yield by microwave synthesis (Figure 5).

\section{Compound 1c}

The reaction of sulfanilamide (3) with benzoyl chloride (2) in $\mathrm{NaOH}$ with shaking, results in the desired $\mathrm{N}-\{[4$ (benzoylamino)phenyl]sulfonyl $\}$ benzamide (1c) in $50 \%$ yield, and in $82 \%$ yield by microwave synthesis (Figure 6 ).

\section{Compound $3 \mathrm{~b}$}

The reaction of sulfamethoxazole (1) with phthalic acid (4) in DMF with refluxing, results in the desired 4-(1,3-dioxo-1,3-dihydro- $2 \mathrm{H}$-isoindol-2-yl)- $\mathrm{N}$-(5methyl-1,2-oxazol-3-yl) benzenesulfonamide (3b) in 50\% yield, and in $88 \%$ yield by microwave synthesis (Figure 7).

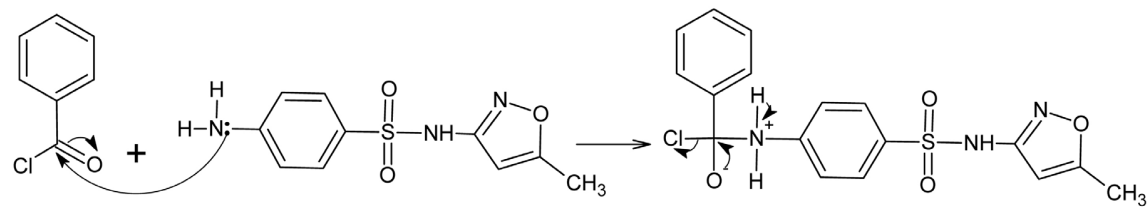

(2)

(1)<smiles>Cc1cc(NS(=O)(=O)c2ccc(NC(=O)c3ccccc3)cc2)no1</smiles>

(1b)

Figure 5. The mechanism of synthesis of $N$-\{4-[(5-methyl-1,2-oxazol-3-yl) sulfamoyl]phenyl\}benzamide (1b).

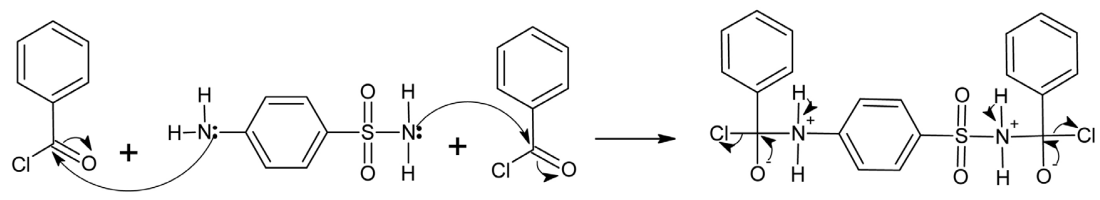

(2)
(2)<smiles>O=C(Nc1ccc(S(=O)(=O)NC(=O)c2ccccc2)cc1)c1ccccc1</smiles>

(1c)

Figure 6. The mechanism of synthesis of $\mathrm{N}-\{[4$ (benzoylamino)phenyl]sulfonyl $\}$ benzamide (1c). 
Table 4. Interaction of the amino acids in 5EDQ with ligands.

\begin{tabular}{|c|c|c|c|c|c|}
\hline ligand & Residue & Interaction & Distance $(\AA)$ & Energy & Van der Waals interaction \\
\hline \multirow{4}{*}{$1 \mathrm{a}$} & Met793 & $\mathrm{O}-\mathrm{H}$ & 3.1 & -2.5 & \multirow{4}{*}{-} \\
\hline & Asp855 & $\mathrm{O}-\mathrm{H}$ & 3.04 & -2.5 & \\
\hline & Asp855 & $\mathrm{O}-\mathrm{H}$ & 2.91 & -1.55509 & \\
\hline & Thr854 & $\mathrm{O}-\mathrm{H}$ & 2.9 & -2.5 & \\
\hline \multirow{2}{*}{$1 b$} & Met793 & $\mathrm{O}-\mathrm{H}$ & 2.66 & -2.5 & \multirow{2}{*}{ Pro794 } \\
\hline & Pro794 & $\mathrm{N}-\mathrm{H}$ & 3.057 & -0.701673 & \\
\hline $1 \mathrm{c}$ & Asp855 & $\mathrm{N}-\mathrm{H}$ & 2.94 & -2.5 & Asp855, Pro794 \\
\hline \multirow{4}{*}{$2 \mathrm{a}$} & Met793 & $\mathrm{O}-\mathrm{H}$ & 2.8 & -2.5 & \multirow{4}{*}{-} \\
\hline & Asp855 & $\mathrm{O}-\mathrm{H}$ & 3.05 & -1.90438 & \\
\hline & Thr854 & $\mathrm{O}-\mathrm{H}$ & 2.9 & -2.5 & \\
\hline & Lys745 & $\mathrm{O}-\mathrm{H}$ & 3 & -2.5 & \\
\hline \multirow{3}{*}{$2 b$} & $\mathrm{Gln} 791$ & $\mathrm{O}-\mathrm{H}$ & 2.6 & -2.5 & \multirow{3}{*}{-} \\
\hline & Met793 & $\mathrm{O}-\mathrm{H}$ & 2.98 & -1.3688 & \\
\hline & Met793 & $\mathrm{O}-\mathrm{H}$ & 2.9 & -2.5 & \\
\hline \multirow{2}{*}{$2 c$} & Ser720 & $\mathrm{O}-\mathrm{H}$ & 3.04 & -0.750539 & \multirow{2}{*}{-} \\
\hline & Gly719 & $\mathrm{O}-\mathrm{H}$ & 2.86 & -2.5 & \\
\hline \multirow{4}{*}{$3 a$} & Met793 & $\mathrm{O}-\mathrm{H}$ & 2.8 & -2.5 & \multirow{4}{*}{-} \\
\hline & Thr854 & $\mathrm{O}-\mathrm{H}$ & 3.03 & -2.5 & \\
\hline & Asp855 & $\mathrm{O}-\mathrm{H}$ & 2.92 & -1.56838 & \\
\hline & Lys745 & $\mathrm{O}-\mathrm{H}$ & 3 & -2.5 & \\
\hline \multirow{3}{*}{$3 b$} & Gly724 & $\mathrm{N}-\mathrm{H}$ & 3.16 & -1.74979 & \multirow{3}{*}{ Gly719 } \\
\hline & Gly724 & $\mathrm{O}-\mathrm{H}$ & 2.85 & -1.35909 & \\
\hline & Ser720 & $\mathrm{N}-\mathrm{H}$ & 2.8 & -2.5 & \\
\hline \multirow{5}{*}{$3 c$} & Lys745 & $\mathrm{O}-\mathrm{H}$ & 3.1 & -2.5 & \multirow{5}{*}{ Val726, Arg841, Gly721 } \\
\hline & Val726 & $\mathrm{O}-\mathrm{H}$ & 3.3 & -0.757545 & \\
\hline & Phe723 & $\mathrm{O}-\mathrm{H}$ & 3 & -2.5 & \\
\hline & Gly724 & $\mathrm{O}-\mathrm{H}$ & 2.65 & -2.5 & \\
\hline & Asp855 & $\mathrm{O}-\mathrm{H}$ & 2.7 & -2.5 & \\
\hline \multirow{3}{*}{$3 d$} & Met793 & $\mathrm{O}-\mathrm{H}$ & 2.8 & -2.5 & \multirow{3}{*}{-} \\
\hline & Thr854 & $\mathrm{O}-\mathrm{H}$ & 2.95 & -2.5 & \\
\hline & Lys745 & $\mathrm{O}-\mathrm{H}$ & 2.8 & -2.5 & \\
\hline $4 \mathrm{a}$ & Phe795 & $\mathrm{O}-\mathrm{H}$ & 3 & -2.5 & - \\
\hline \multirow{2}{*}{$4 b$} & Lys745 & $\mathrm{O}-\mathrm{H}$ & 2.77 & -2.5 & \multirow{2}{*}{$\begin{array}{l}\text { Leu788, Thr790, } \\
\text { Lys745, Asp855 }\end{array}$} \\
\hline & Cys797 & $\mathrm{N}-\mathrm{H}$ & 3.1 & -2.5 & \\
\hline
\end{tabular}




\section{Continued}

\begin{tabular}{|c|c|c|c|c|c|}
\hline $4 c$ & Lys745 & $\mathrm{O}-\mathrm{H}$ & 3.1 & -0.195019 & $\begin{array}{l}\text { Glu762, Lys745, } \\
\text { Gly719, Asp855 }\end{array}$ \\
\hline $5 a$ & Thr854 & $\mathrm{O}-\mathrm{H}$ & 3.17 & -2.10359 & Leu844 \\
\hline \multirow{3}{*}{$5 b$} & Ser720 & $\mathrm{N}-\mathrm{H}$ & 2.7 & -2.5 & \multirow{3}{*}{ Glu762 } \\
\hline & Lys745 & $\mathrm{N}-\mathrm{H}$ & 2.7 & -1.08594 & \\
\hline & Lys745 & $\mathrm{O}-\mathrm{H}$ & 2.8 & -2.08639 & \\
\hline $5 c$ & Met793 & $\mathrm{O}-\mathrm{H}$ & 3 & -2.38289 & Val726, Leu747 \\
\hline $6 a$ & Thr854 & $\mathrm{O}-\mathrm{H}$ & 3 & -1.74103 & $\begin{array}{l}\text { Leu792, Gly796, } \\
\text { Pro794, Leu844 }\end{array}$ \\
\hline $6 b$ & Leu718 & $\mathrm{N}-\mathrm{H}$ & 3 & -2.5 & - \\
\hline $6 c$ & Thr854 & $\mathrm{O}-\mathrm{H}$ & 2.7 & -2.5 & Lys745, Met793, Val726 \\
\hline \multirow{4}{*}{$7 \mathrm{a}$} & Gly719 & $\mathrm{N}-\mathrm{H}$ & 2.85 & -1.99386 & \multirow{4}{*}{ Phe723 } \\
\hline & Lys745 & $\mathrm{O}-\mathrm{H}$ & 3.2 & -1.95469 & \\
\hline & Cys797 & $\mathrm{O}-\mathrm{H}$ & 3.3 & -1.34206 & \\
\hline & Asp800 & $\mathrm{O}-\mathrm{H}$ & 3.06 & -2.49205 & \\
\hline \multirow{5}{*}{$7 \mathrm{~b}$} & Gly719 & N-H & 3.06 & -0.808774 & \multirow{5}{*}{ Ser720 } \\
\hline & Gly721 & $\mathrm{N}-\mathrm{H}$ & 3.1 & -0.651249 & \\
\hline & Ser720 & $\mathrm{N}-\mathrm{H}$ & 2.6 & -2.42948 & \\
\hline & Gly724 & $\mathrm{N}-\mathrm{H}$ & 3.17 & -1.54498 & \\
\hline & Gly724 & $\mathrm{O}-\mathrm{H}$ & 3 & -1.1997 & \\
\hline \multirow{2}{*}{$7 c$} & Met793 & $\mathrm{O}-\mathrm{H}$ & 2.93 & -2.36929 & \multirow{2}{*}{ Lys745, Ala743 } \\
\hline & Asp855 & $\mathrm{N}-\mathrm{H}$ & 3.1 & -0.133077 & \\
\hline \multirow{3}{*}{$8 a$} & Met793 & $\mathrm{O}-\mathrm{H}$ & 3.3 & -1.22411 & \multirow{3}{*}{-} \\
\hline & Thr854 & $\mathrm{O}-\mathrm{H}$ & 2.8 & -2.5 & \\
\hline & Lys745 & $\mathrm{O}-\mathrm{H}$ & 3 & -2.5 & \\
\hline $8 b$ & Ser720 & $\mathrm{N}-\mathrm{H}$ & 2.6 & -1.84127 & Met793 \\
\hline \multirow{2}{*}{$8 c$} & Thr854 & $\mathrm{O}-\mathrm{H}$ & 2.84 & -2.5 & \\
\hline & Lys745 & $\mathrm{O}-\mathrm{H}$ & 2.94 & -2.5 & \\
\hline
\end{tabular}

\section{Compound 3d}

The reaction of sulfanilamide (3) with phthalic acid (4) in DMF with refluxing, results in the desired 4-(1,3-dioxo-1,3-dihydro- $2 H$-isoindol-2-yl) benzenesulfonamide (3d) in $91 \%$ yield, and in $97 \%$ yield by microwave synthesis (Figure 8).

\section{- Analytical data}

$N$-\{4-[(5-methyl-1,2-oxazol-3-y) sulfamoyl] phenyl\}benzamide (1b)

White powder, mp $278^{\circ} \mathrm{C}-280^{\circ} \mathrm{C}$. TLC; the mobile phase was used acetate 


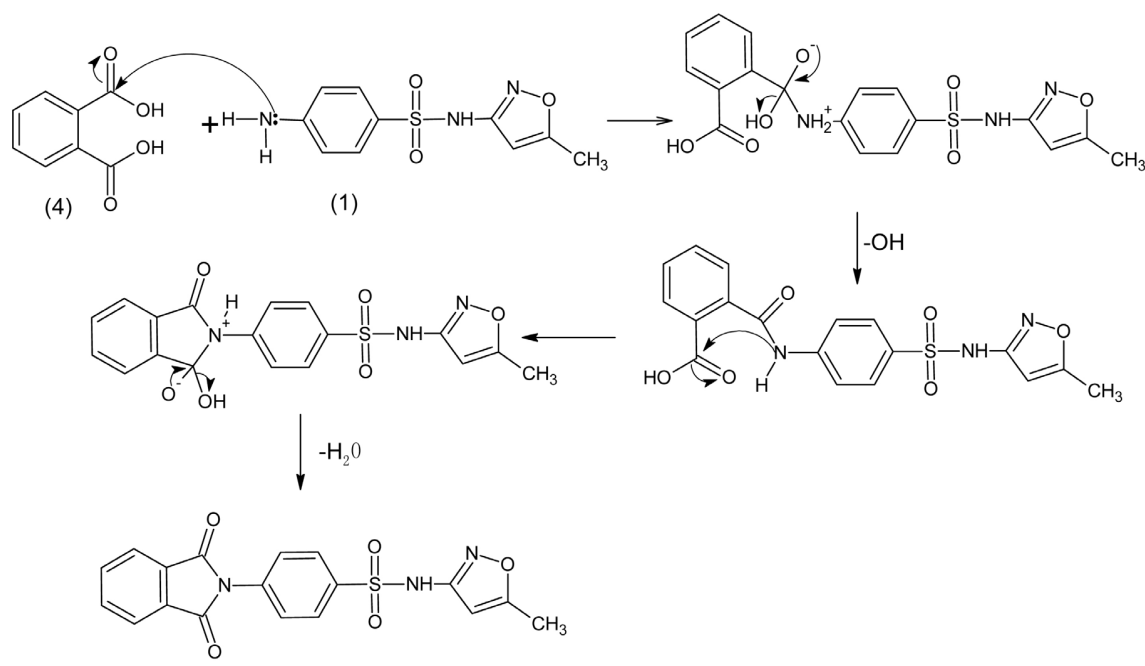

(3b)

Figure 7. The mechanism of synthesis of 4-(1,3-dioxo-1,3-dihydro- $2 \mathrm{H}$-isoindol-2-yl)- $\mathrm{N}$ (5-methyl-1,2-oxazol-3-yl)benzenesulfonamide (3b).

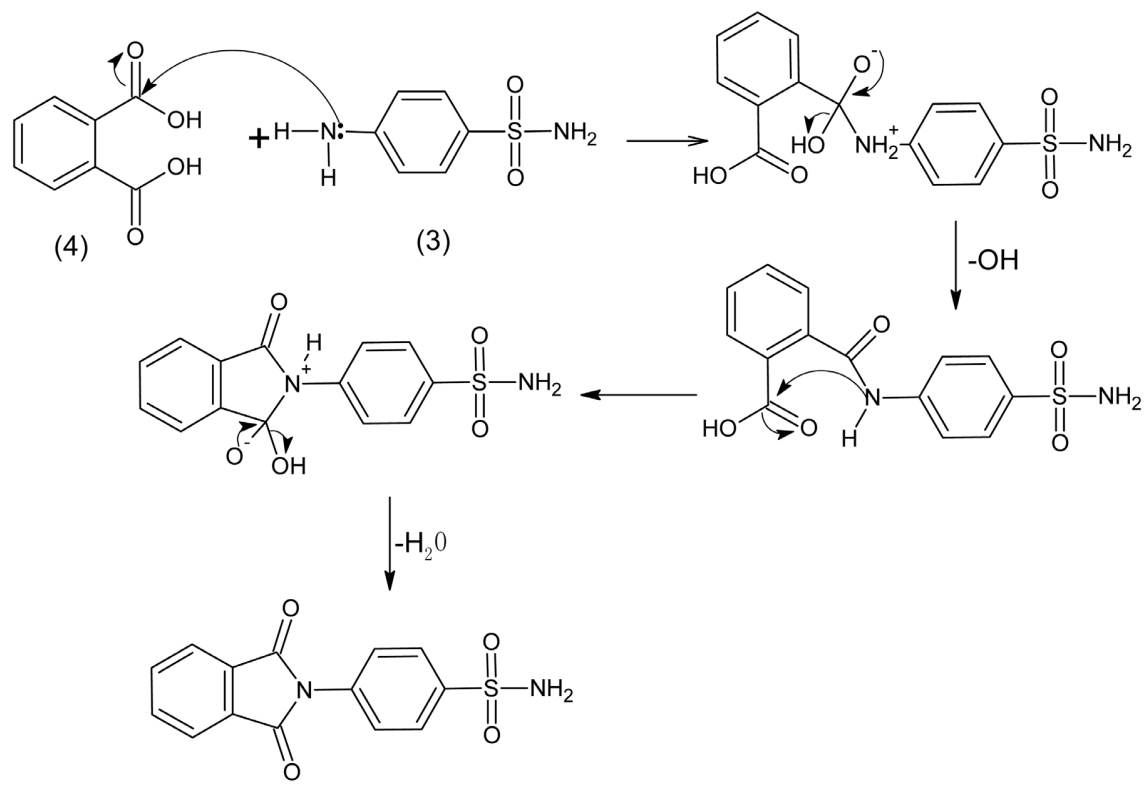

(3d)

Figure 8. The mechanism of synthesis of 4-(1,3-dioxo-1,3-dihydro-2 $\mathrm{H}$-isoindol-2-yl) benzenesulfonamide (3d).

ethyl: petrolatum ether 9:1, which the Rf for sulfamethoxazole 0.8 and the $\mathrm{Rf}$ for compound (1b) 0.88. IR spectrum ( $\left.v \max , \mathrm{cm}^{-1}\right): 3362(\mathrm{~N}-\mathrm{H}), 3061(\mathrm{C}-\mathrm{H}$ arom), 2987, $2882(\mathrm{C}-\mathrm{H}), 1660(\mathrm{C}=\mathrm{O})$, 1604, 1589, $1578(\mathrm{C}=\mathrm{C}), 1529(\mathrm{~N}-\mathrm{O}), 1372,1332$ $(\mathrm{S}=\mathrm{O}), 1318(\mathrm{C}-\mathrm{N})$ (Figure 9) [26]. ${ }^{1} \mathrm{H}-\mathrm{NMR}$ spectrum (DMSO-d $\left.{ }_{6}, \delta, \mathrm{ppm}\right): 2.3$ $\left(\mathrm{s}, 3 \mathrm{H}, \mathrm{CH}_{3}\right), 6.1(\mathrm{~s}, 1 \mathrm{H},=\mathrm{CH}-), 7.5(\mathrm{t}, 1 \mathrm{H}, \mathrm{Ar}-\mathrm{H}), 7.58(\mathrm{t}, 1 \mathrm{H}, \mathrm{Ar}-\mathrm{H}), 7.8(\mathrm{~d}$, $1 \mathrm{H}, \mathrm{Ar}-\mathrm{H}), 7.9$ (d, 1H, Ar-H), 7.97 (d, 1H, Ar-H), 10.6 (s, 1H, NH), 11.3 (s, 1H, $\mathrm{SO}_{2}-\mathrm{NH}$ ) (Figure 10). ${ }^{13} \mathrm{C}-\mathrm{NMR}$ (DMSO-d $\mathrm{d}_{6}, \delta$, ppm): 12.5, 96, 120.5, 128.3, $128.4,129,132.5,135,144,158,166.6,170.8$ (Figure 11) [27]. Mass spectrum 


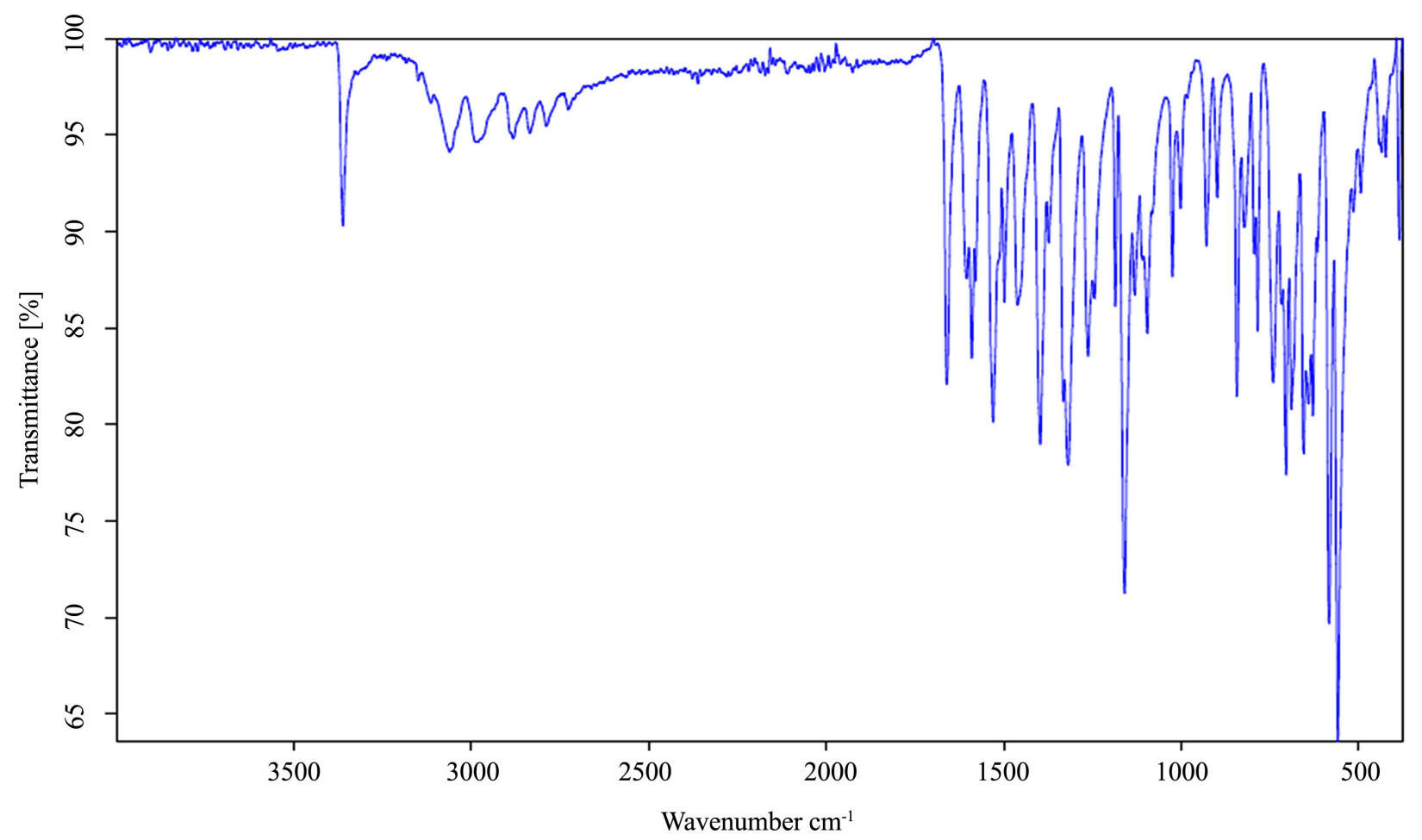

Figure 9. IR spectrum for $1 \mathrm{~b}$ compound.

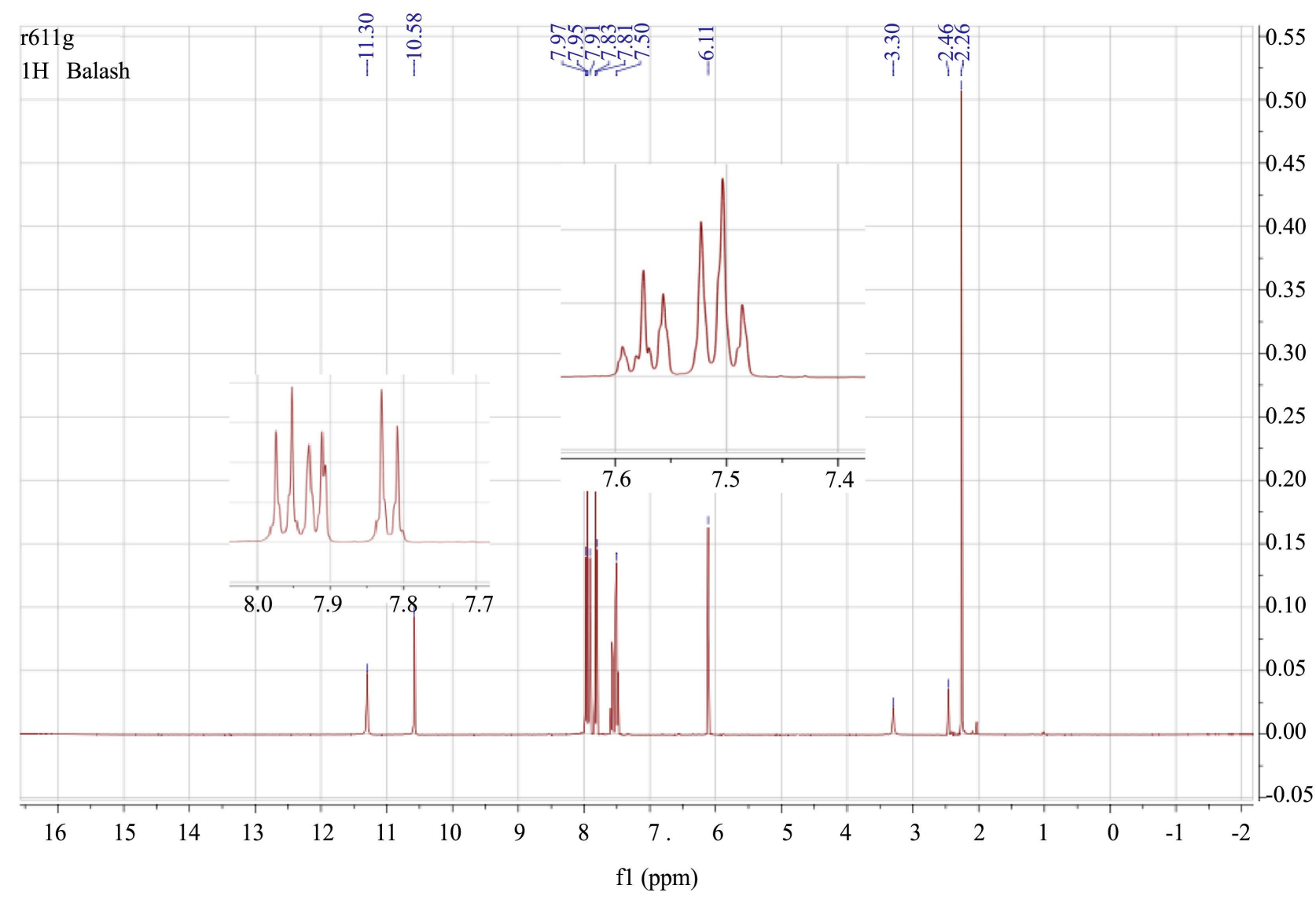

Figure $10 .{ }^{1} \mathrm{H}-\mathrm{NMR}$ spectrum for $1 \mathrm{~b}$ compound. 


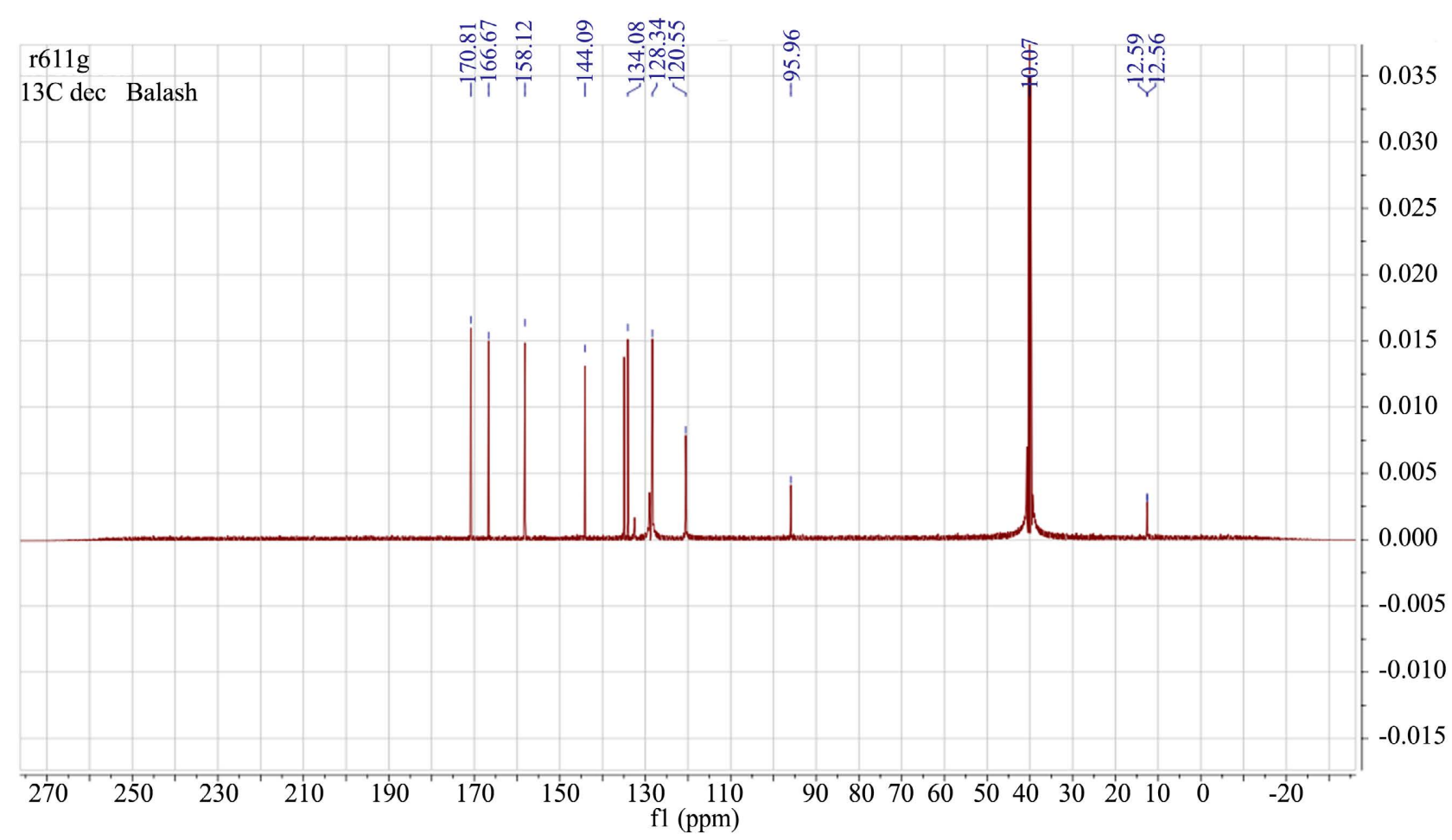

Figure $11 .{ }^{13} \mathrm{C}-\mathrm{NMR}$ spectrum for $1 \mathrm{~b}$ compound.

( $\mathrm{m} / \mathrm{z}, \mathrm{ESI})$ : showed molecular ion $[\mathrm{M}+\mathrm{H}]^{+}$peak at 358.12 corresponding to the molecular formula of $\mathrm{C}_{17} \mathrm{H}_{15} \mathrm{~N}_{3} \mathrm{O}_{4} \mathrm{~S}$, and $[\mathrm{M}+\mathrm{Na}]^{+}$peak at 380.07.

$N-\{[4$ (benzoylamino) phenyl] sulfony\} benzamide (1c)

White powder, mp $296^{\circ} \mathrm{C}-300^{\circ} \mathrm{C}$. TLC; the mobile phase was used acetate ethyl: petrolatum ether 9:1, which the $\mathrm{Rf}$ for sulfanilamide 0.69 and the $\mathrm{Rf}$ for compound (1c) 0.79. IR spectrum $\left(\nu \max , \mathrm{cm}^{-1}\right): 3359,3264(\mathrm{~N}-\mathrm{H}), 1650(\mathrm{C}=\mathrm{O})$, 1590, 1513, $1484(\mathrm{C}=\mathrm{C}), 1396,1294(\mathrm{~S}=\mathrm{O}), 1266(\mathrm{C}-\mathrm{N})$ (Figure 12) [26]. ${ }^{1} \mathrm{H}-\mathrm{NMR}$ spectrum (DMSO- $\left.\mathrm{d}_{6}, \delta, \mathrm{ppm}\right): 7.2(\mathrm{t}, 1 \mathrm{H}, \mathrm{Ar}-\mathrm{H}), 7.5(\mathrm{t}, 1 \mathrm{H}, \mathrm{Ar}-\mathrm{H})$, $7.55(\mathrm{t}, 1 \mathrm{H}, \mathrm{Ar}-\mathrm{H}), 7.75$ (d, 1H, Ar-H), 7.8 (d, 1H, Ar-H), 7.95 (d, 1H, Ar-H), $10.5(\mathrm{~s}, 1 \mathrm{H}, \mathrm{NH})$ (Figure 13). ${ }^{13} \mathrm{C}-\mathrm{NMR}\left(\mathrm{DMSO}_{6}, \delta, \mathrm{ppm}\right): 120.3,127.05$, 127.1, 128.3, 128.29, 128.31, 129, 132.4, 135.02, 135.04, 139.25, 139.3, 142.7, 166.5 (Figure 14) [27]. MS (m/z, ESI): The major peak for compound showed molecular ion $[\mathrm{M}+\mathrm{H}]^{+}$peak at 381.15 corresponding to the molecular formula of $\mathrm{C}_{22} \mathrm{H}_{20} \mathrm{~N}_{2} \mathrm{O}_{2} \mathrm{~S}$, and $[\mathrm{M}+\mathrm{Na}]^{+}$peak at 403.21.

4-(1,3-dioxo-1,3-dihydro-2H-isoindol-2-yl) - $N$-(5-methyl-1,2-oxazol-3-yl) ben zenesulfonamide (3b)

Pale white powder, $\mathrm{mp} 255^{\circ} \mathrm{C}-258^{\circ} \mathrm{C}$. TLC; the mobile phase was used acetate ethyl: petrolatum ether 7:3, which the $\mathrm{Rf}$ for sulfamethoxazole 0.67 and the Rf for compound (3b) 0.8. IR spectrum $\left(v \max , \mathrm{cm}^{-1}\right)$ : $3476(\mathrm{~N}-\mathrm{H}), 3107(\mathrm{C}-\mathrm{H}$ arom), 3026, $3001(\mathrm{C}-\mathrm{H})$, 1739, 1713 (C=O), 1610, 1594, 1500 (C=C), 1413, 1380 $(\mathrm{S}=\mathrm{O}), 1333(\mathrm{C}-\mathrm{N})$ (Figure 15) [26]. ${ }^{1} \mathrm{H}-\mathrm{NMR}$ spectrum (DMSO- $\left.\mathrm{d}_{6}, \delta, \mathrm{ppm}\right): 2.3$ (s, 3H, $\left.\mathrm{CH}_{3}\right), 6.1(\mathrm{~s}, 1 \mathrm{H},=\mathrm{CH}-), 7.7(\mathrm{~d}, 1 \mathrm{H}, \mathrm{Ar}-\mathrm{H}), 7.9(\mathrm{~d}, 1 \mathrm{H}, \mathrm{Ar}-\mathrm{H}), 7.95(\mathrm{~d}$, $1 \mathrm{H}, \mathrm{Ar}-\mathrm{H}), 8(\mathrm{~d}, 1 \mathrm{H}, \mathrm{Ar}-\mathrm{H}), 11.5\left(\mathrm{~s}, 1 \mathrm{H}, \mathrm{SO}_{2}-\mathrm{NH}\right)$ (Figure 16$) .{ }^{13} \mathrm{C}-\mathrm{NMR}$ 


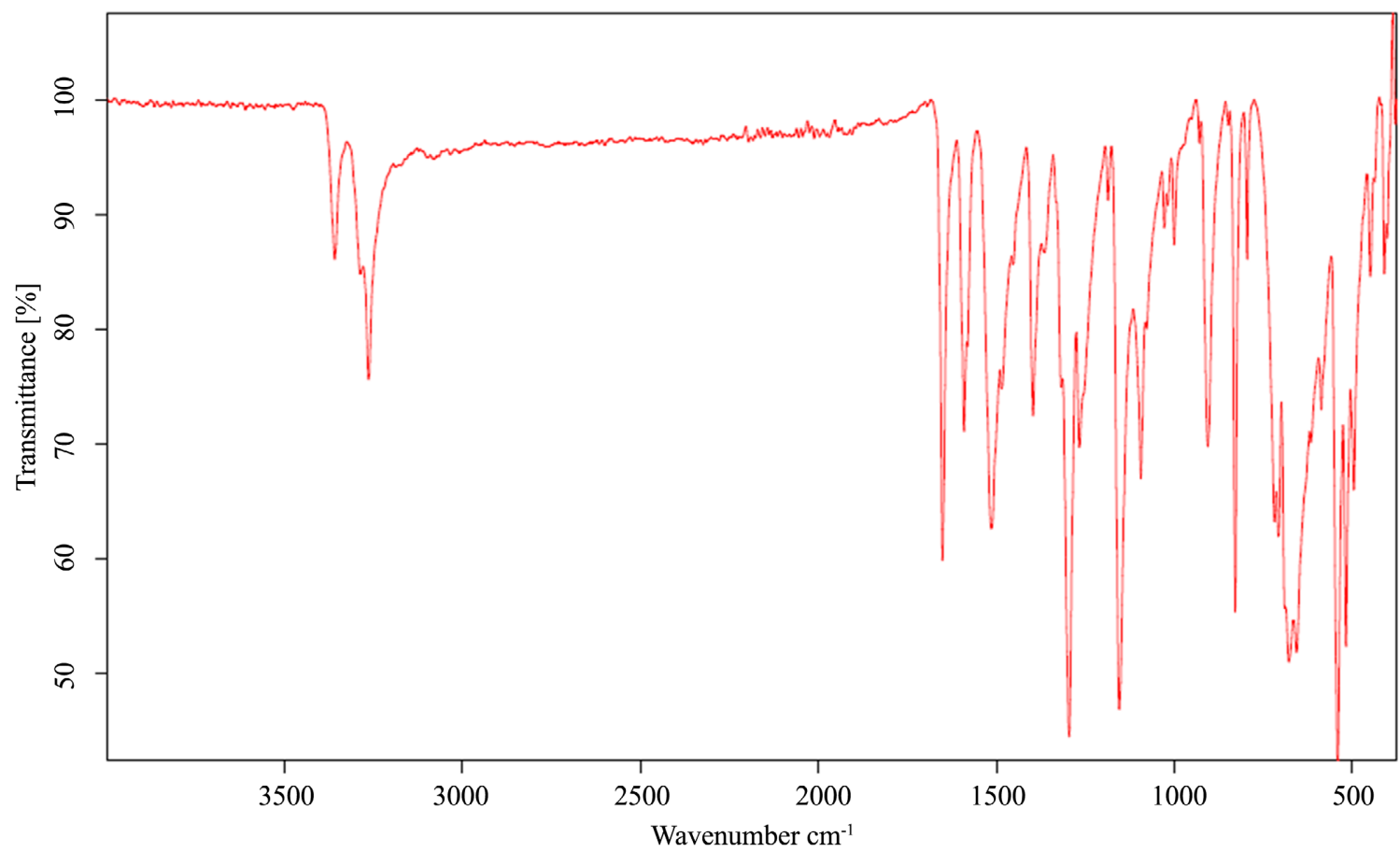

Figure 12. IR spectrum for 1c compound.

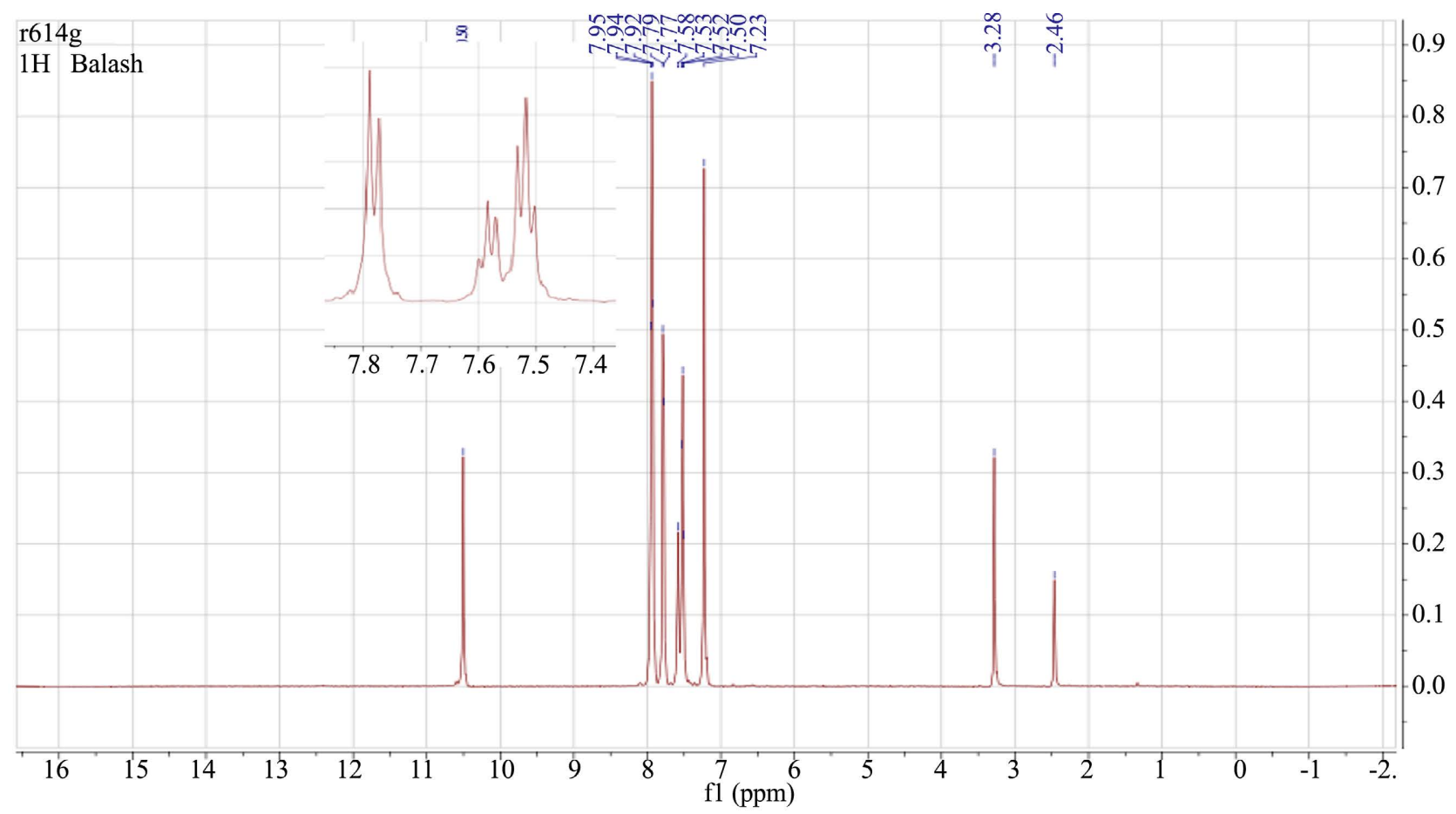

Figure 13. ${ }^{1} \mathrm{H}-\mathrm{NMR}$ spectrum for $1 \mathrm{c}$ compound.

(DMSO-d 6 , $\delta$ ppm): 12.5, 96, 124.1, 128, 128.2, 132, 135.5, 136.7, 138.9, 158, 167, 171 (Figure 17) [27]. MS (m/z, ESI): showed $[\mathrm{M}+\mathrm{H}]^{+}$peak at 384.05 corresponding to the molecular formula of $\mathrm{C}_{18} \mathrm{H}_{13} \mathrm{~N}_{3} \mathrm{O}_{5} \mathrm{~S}$, and $[\mathrm{M}+\mathrm{Na}]^{+}$peak at 406.03 


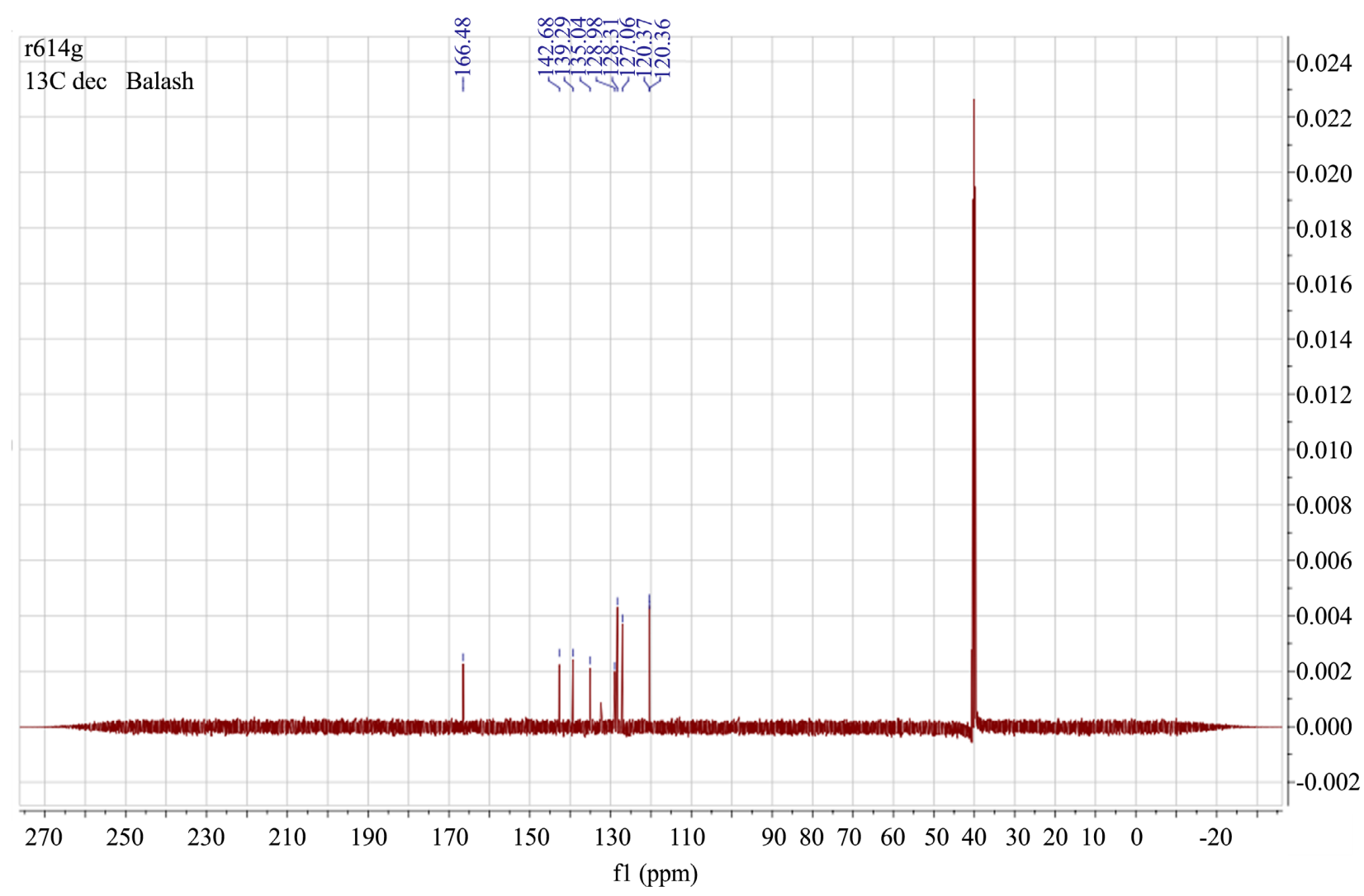

Figure $14 .{ }^{13} \mathrm{C}-\mathrm{NMR}$ spectrum for $1 \mathrm{c}$ compound.

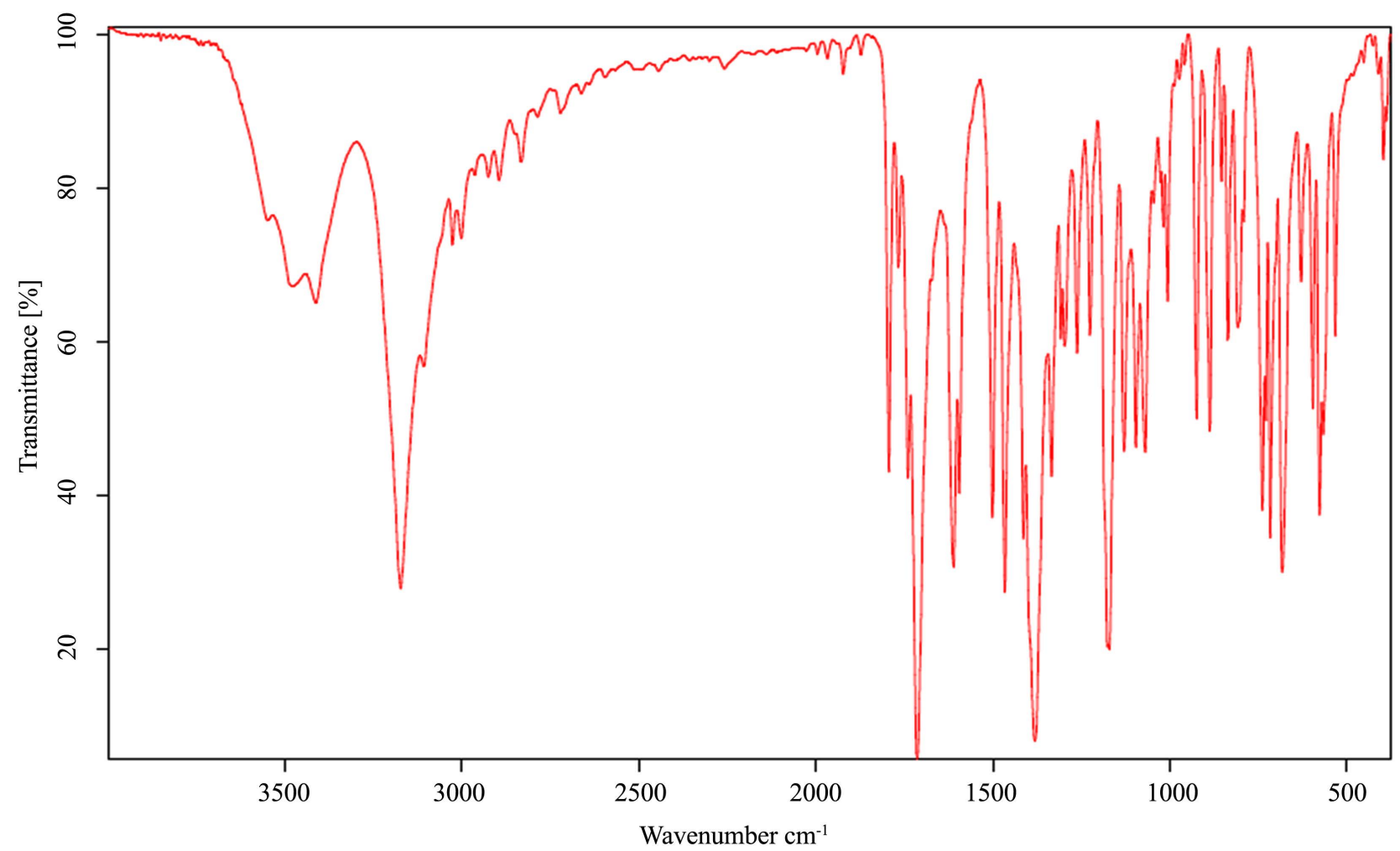

Figure 15. IR spectrum for $3 \mathrm{~b}$ compound. 


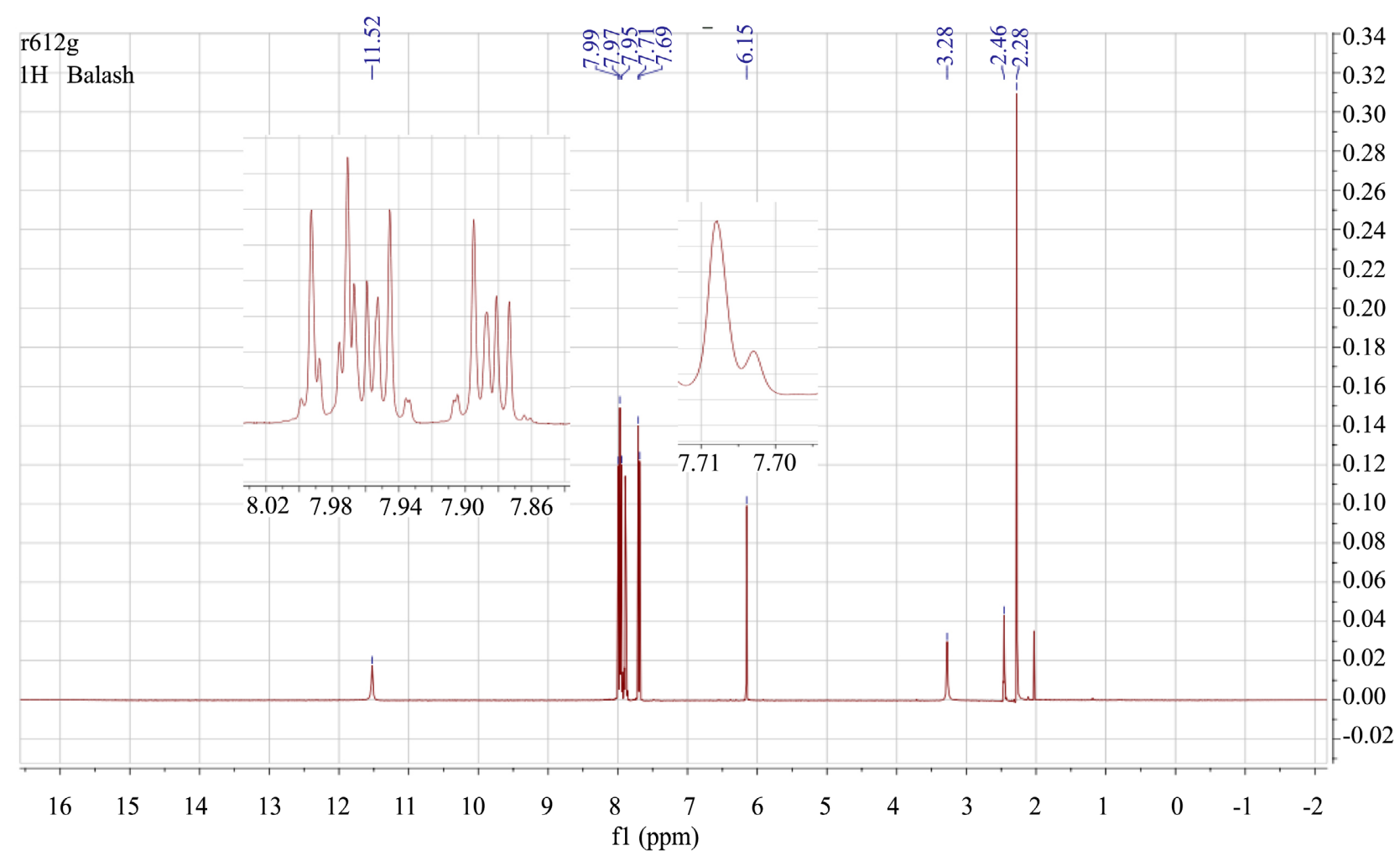

Figure 16. ${ }^{1} \mathrm{H}-\mathrm{NMR}$ spectrum for $3 \mathrm{~b}$ compound.

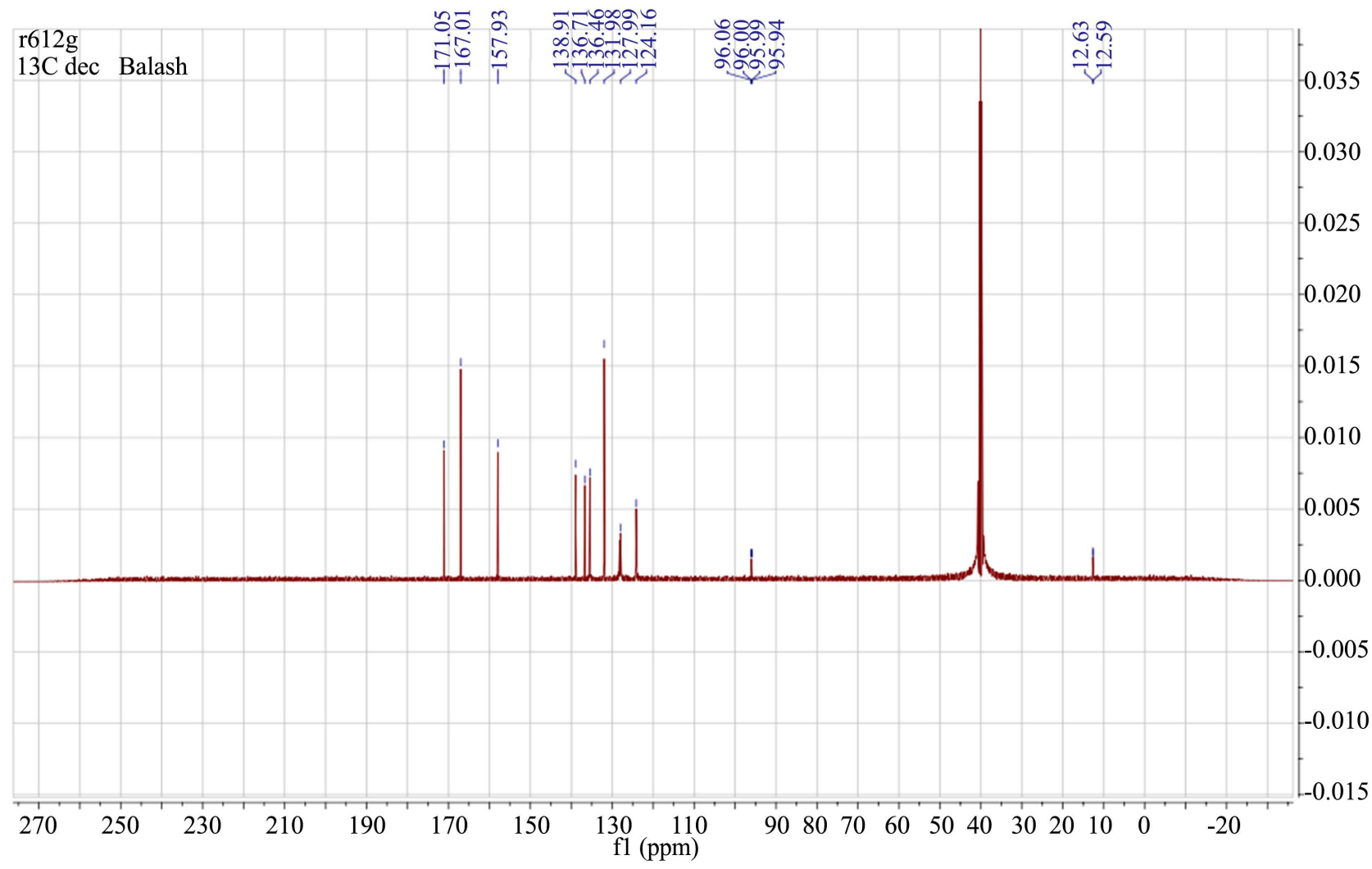

Figure 17. ${ }^{13} \mathrm{C}-\mathrm{NMR}$ spectrum for $3 \mathrm{~b}$ compound. 


\section{4-(1,3-dioxo-1,3-dihydro-2H-isoindol-2-y) benzenesulfonamide (3d)}

White powder, $\mathrm{mp} 364^{\circ} \mathrm{C}-368^{\circ} \mathrm{C}$. TLC; the mobile phase was used acetate ethyl: petrolatum ether 6:4, which the $\mathrm{Rf}$ for sulfanilamide 0.44 and the $\mathrm{Rf}$ for compound (3d) 0.62. IR spectrum $\left(v \max , \mathrm{cm}^{-1}\right): 3362,3258(\mathrm{~N}-\mathrm{H}), 1703(\mathrm{C}=\mathrm{O})$, 1615, 1594, $1498(\mathrm{C}=\mathrm{C}), 1393,1340(\mathrm{~S}=\mathrm{O}), 1299,1286(\mathrm{C}-\mathrm{N}), 1224(\mathrm{C}-\mathrm{O})$ (Figure 18) [26]. ${ }^{1} \mathrm{H}-\mathrm{NMR}$ spectrum (DMSO-d $\mathrm{d}_{6}, \delta$, ppm): $7.4\left(\mathrm{~s}, 1 \mathrm{H}, \mathrm{SO}_{2}-\mathrm{NH}\right)$, $7.66(\mathrm{~d}, 1 \mathrm{H}, \mathrm{Ar}-\mathrm{H}), 7.88$ (d, 1H, Ar-H), 7.93 (t, 1H, Ar-H), 7.95 (d, 1H, Ar-H) (Figure 19). ${ }^{13} \mathrm{C}-\mathrm{NMR}$ (DMSO- $\mathrm{d}_{6}, \delta, \mathrm{ppm}$ ): 124, 127, 128, 132, 135.3, 135.5, 143.8, 167.18 (Figure 20) [27]. MS ( $\mathrm{m} / \mathrm{z}, \mathrm{ESI}$ ): showed $[\mathrm{M}+2 \mathrm{H}]^{+}$peak at 304.26 corresponding to the molecular formula of $\mathrm{C}_{14} \mathrm{H}_{10} \mathrm{~N}_{2} \mathrm{O}_{4} \mathrm{~S}$, and $[\mathrm{M}+\mathrm{Na}]^{+}$peak at 325.03.

All the designed compounds were bound to receptors and given energy docking. Only one compound showed higher docking scores toward the receptor than the reference ligand, Table 3 . The compounds $4 \mathrm{~b}, 6 \mathrm{c}$, and $5 \mathrm{~b}$ were shown higher energy binding with EGFR (TMLR) binding pocket than other compounds.

Most of the compounds were given hydrogen bonds and van der Waals bonds to receptors with different bond lengths and binding energies. The ligand displayed hydrogen bonds with 9 amino acid residues of 5EDQ: Thr854, Lys745, Asn842, Asp855, Met793, Arg858, Arg841. To stabilize the compounds in the binding pocket; most compounds displayed van der Waals interactions between the amino acid residues and the ligands.

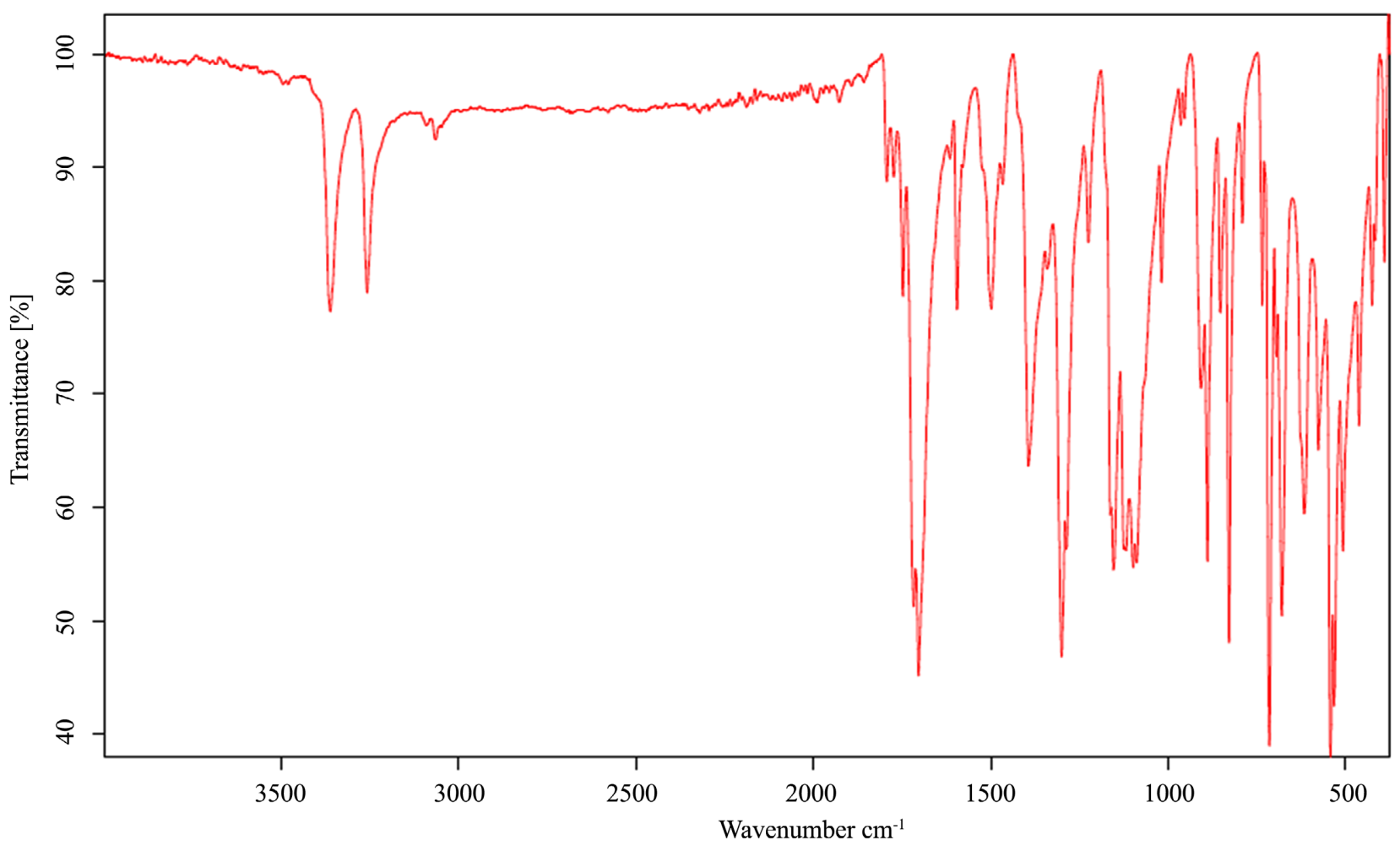

Figure 18. IR spectrum for $3 \mathrm{~d}$ compound. 


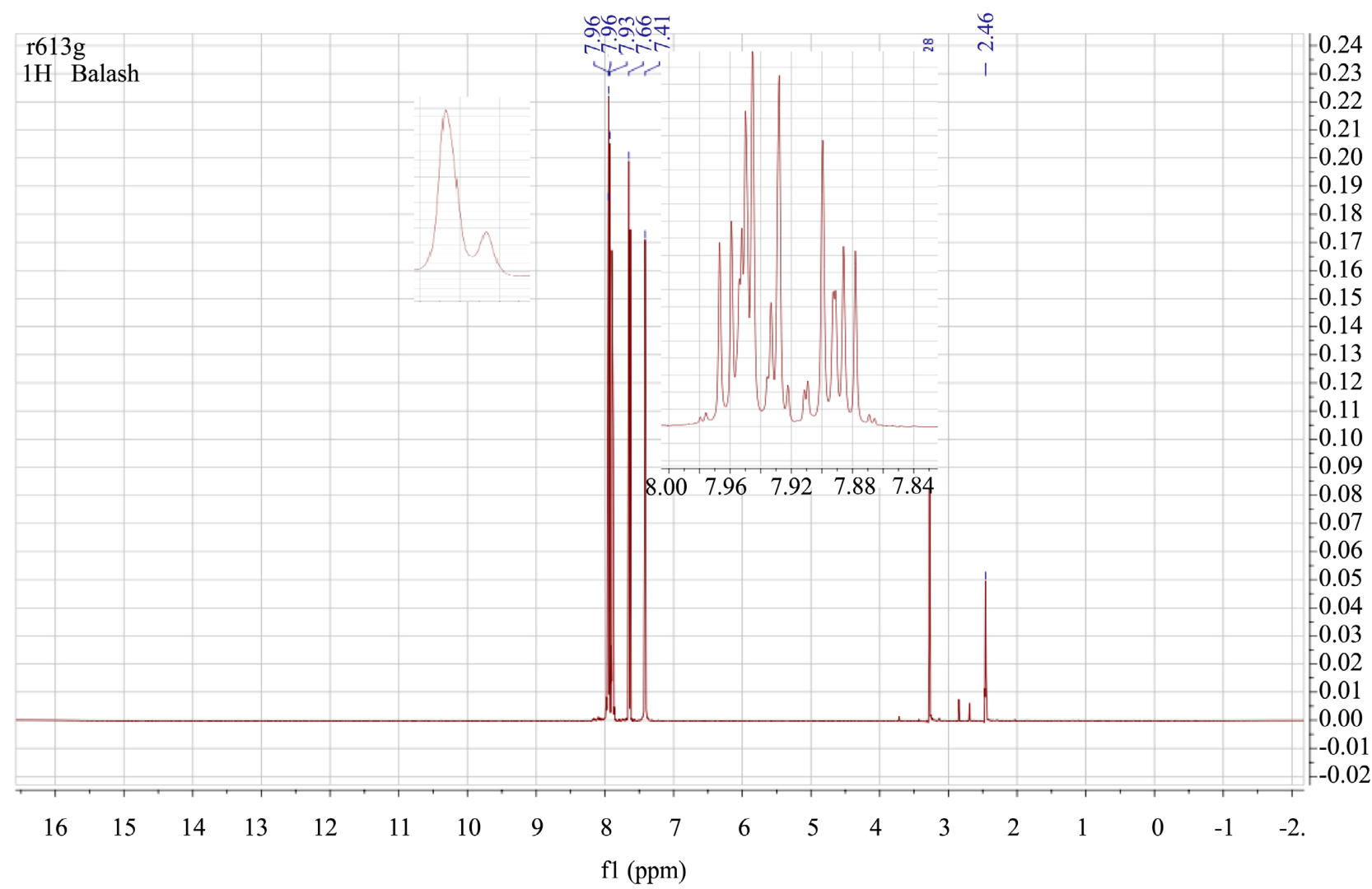

Figure 19. ${ }^{1} \mathrm{H}-\mathrm{NMR}$ spectrum for $3 \mathrm{~d}$ compound.

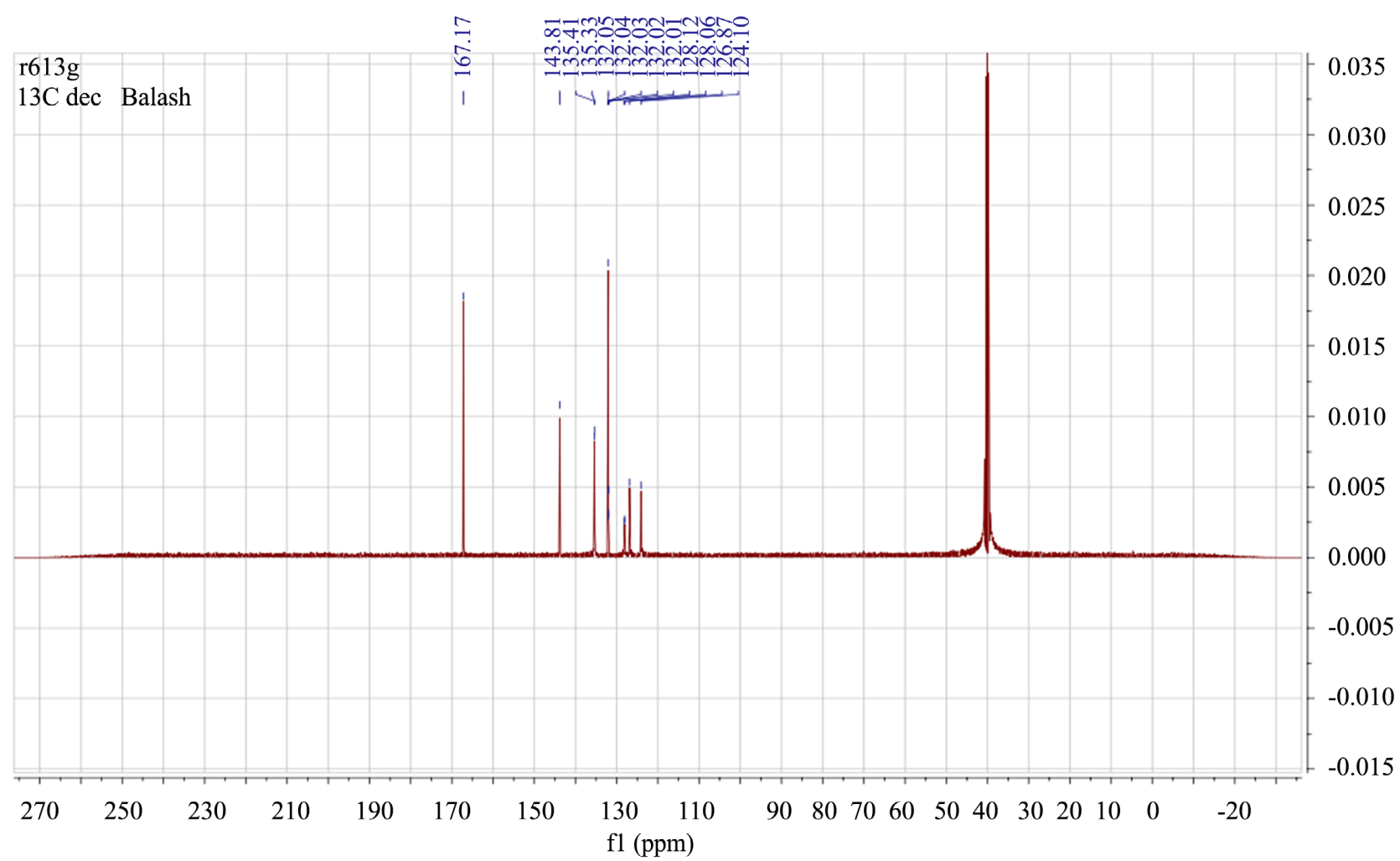

Figure $20 .{ }^{13} \mathrm{C}-\mathrm{NMR}$ spectrum for $3 \mathrm{~d}$ compound. 
The predicted binding modes of $4 \mathrm{~b}$ and $6 \mathrm{c}$ and their interactions with the residues in the EGFR (TMLR) binding pocket are shown in (Figure 21).

A series of four sulfonamides were synthesized in basic media by simple reactions of amino-group-containing drug; sulfamethoxazole and sulfanilamide with carbonyl group in benzoyl chloride and phthalic acid. The compounds were obtained in good to excellent yield (50\%-91\%), and the yield by microwave synthesis was excellent $(82 \%$ - 97\%). The synthesized compounds were characterized by FT-IR; the characteristics band at $3258-3476 \mathrm{~cm}^{-1}$ for $(\mathrm{N}-\mathrm{H})$ and 1650 - $1739 \mathrm{~cm}^{-1}$ for $(\mathrm{C}=\mathrm{O})$ and $1413-1294 \mathrm{~cm}^{-1}$ of $\mathrm{S}=\mathrm{O}$ stretching and $1266-1333$ $\mathrm{cm}^{-1}$ for (C-N) for all compounds reveals the formation of sulfonamides. Mass spectral data of all synthesized compounds was obtained by ESI-MS. The major peak for compounds was showed good agreement with the calculated molecular masses of the concerned compound. The structures of all the compounds were also confirmed by ${ }^{1} \mathrm{H}$ NMR by dissolving in DMSO. ${ }^{1} \mathrm{H}$ NMR spectra of compounds,
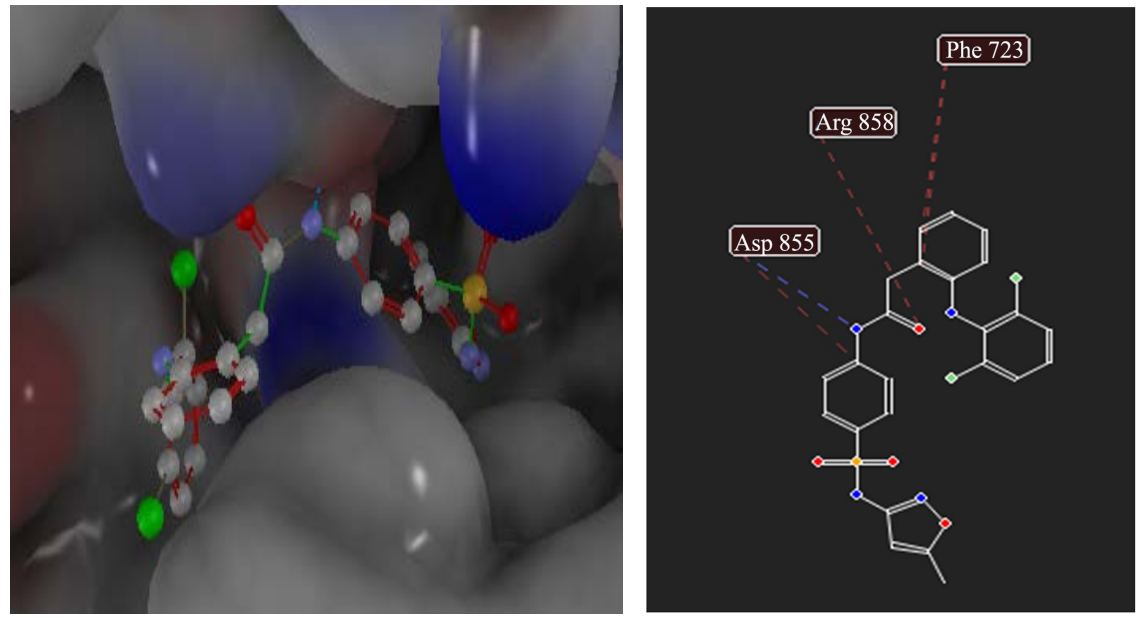

(a)
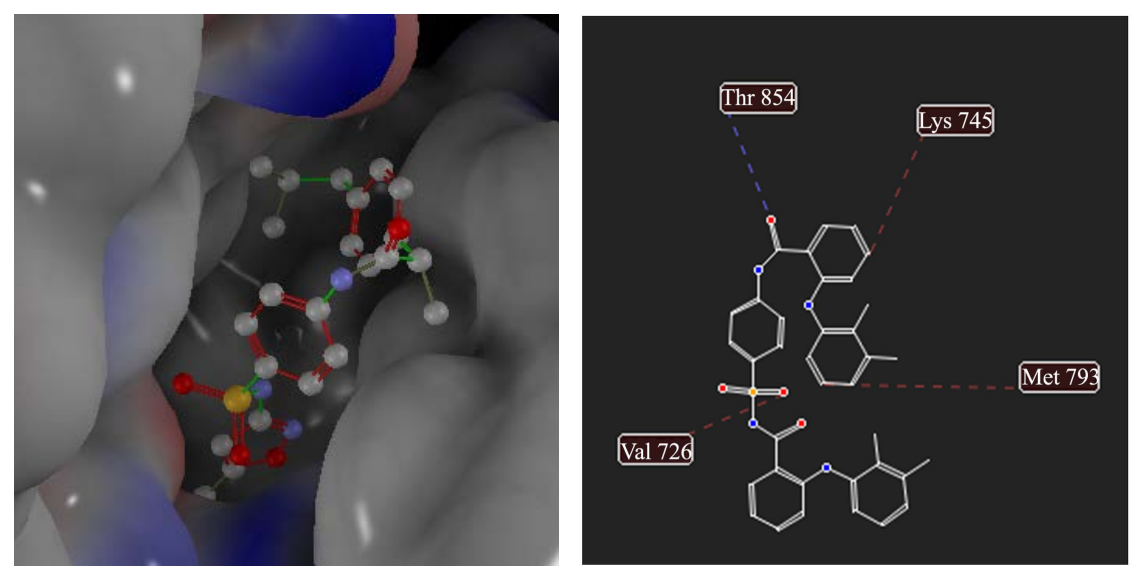

(b)

Figure 21. (a) Docking solution of compound (4b) and the interactions with residues of amino acid in the TMLR binding pocket; (b) docking solution of compound (6c) and the interactions with residues of amino acid in the TMLR binding pocket. Blue bonds indicate hydrogen bonds, and red bonds indicate van der Waals. 
Table 5. Comparison of conventional heating method and microwave synthesis.

\begin{tabular}{|c|c|c|c|c|c|c|c|c|}
\hline \multirow{2}{*}{ Conditions } & \multicolumn{2}{|c|}{$\begin{array}{l}\text { Compound } \\
1 \mathrm{~b}\end{array}$} & \multicolumn{2}{|c|}{$\begin{array}{l}\text { Compound } \\
1 \mathrm{c}\end{array}$} & \multicolumn{2}{|c|}{$\begin{array}{c}\text { Compound } \\
\text { 3b }\end{array}$} & \multicolumn{2}{|c|}{$\begin{array}{l}\text { Compound } \\
3 \mathrm{~d}\end{array}$} \\
\hline & $\mathrm{C}$ & M & $\mathrm{C}$ & M & $\mathrm{C}$ & M & $\mathrm{C}$ & M \\
\hline Temperature $\left({ }^{\circ} \mathrm{C}\right)$ & 70 & 120 & - & 100 & 200 & 200 & 200 & 200 \\
\hline Time (min) & 30 & 10 & 30 & 5 & 240 & 20 & 210 & 20 \\
\hline Yield (\%) & 84 & 89 & 50 & 82 & 50 & 88 & 91 & 97 \\
\hline
\end{tabular}

${ }^{\star} \mathrm{C}$ : conventional heating, ${ }^{\star} \mathrm{M}$ : microwave heating.

there were two signals for solvent at 2.5 and $3.3 \mathrm{ppm}$. The protons for the benzene ring appeared at $7.2-8 \mathrm{ppm}$. In $1 \mathrm{~b}$ and $3 \mathrm{~b}$ compounds, there were signals in 2.3 and 6.1 for methyl and $\mathrm{CH}$ in oxazole, respectively. In the ${ }^{13} \mathrm{C}$ NMR spectra for compounds, there was a signal for solvent at $40 \mathrm{ppm}$. Aromatic carbons of benzene ring appeared at chemical shift $120.3-144 \mathrm{ppm}$. The chemical shift value of $\mathrm{C}=\mathrm{O}$ was observed at 166.5 - $167.18 \mathrm{ppm}$. In $\mathbf{1 b}$ and $3 \mathrm{~b}$ compounds, three carbons were visible at 96,158 and $171 \mathrm{ppm}$, and the carbon for methyl group was noted at chemical shift $12.5 \mathrm{ppm}$.

From the results, all the newly synthesized compounds are in agreement with the spectroscopic analysis. And we noted that the microwave synthesis gave a higher yield than the conventional heating method with less time and higher temperature (Table 5).

\section{Conclusion}

Several sulfonamide derivatives were docked into the EGFR (TMLR) binding pocket using the Molegro Virtual Docker software. The binding free energy was calculated to predict their affinity toward EGFR kinase TMLR to select novel candidates as EGFR inhibitors for treating cancer. The results showed that $4 \mathrm{~b}$, and $6 \mathrm{c}$ gave the highest energy docking $-147.213,-132.14 \mathrm{Kcal} / \mathrm{mol}$ toward the EGFR (TMLR) receptor. Their corresponding binding modes were predicted. The obtained results suggested that these compounds may be novel candidates in lung cancer treatment by targeting EGFR tyrosine kinase T790M/L858R. Then, some of new sulfonamide derivatives were synthesized with a simple procedure in one step starting from sulfanilamide and sulfamethoxazole with benzoyl chloride and phthalic acid in basic media. The reactions conditions were easy and excellent yields of compounds were obtained and progress of reaction was monitored by TLC and their structures were confirmed by spectral and elemental analysis. These novel sulfonamide derivatives were also synthesized in rationally good yields by the microwave-assisted method. This is environmentally compassionate technique which gives higher yields and lesser reaction time and easy work-up method. Finally, more studies are still needed to identify the mechanism of action of these derivatives and we are hoping that it will show significant anticancer activity. 


\section{Acknowledgements}

The authors are thankful to University of Marburg, Institute of Pharmacy, Department of Pharmaceutical Chemistry, Germany, for analyze our synthesized compounds by IR spectrum, mass spectrum, and H-NMR and ${ }^{13} \mathrm{C}$ NMR spectrum.

\section{Conflicts of Interest}

The authors declare no conflicts of interest regarding the publication of this paper.

\section{References}

[1] Irfan, A., Batool, F., Irum, S., Ullah, S. and Umer, M. (2018) A Therapeutic Journey of Sulfonamide Derivatives as Potent Anti-Cancer Agents: A Review. World Journal of Pharmaceutical Research, 7, 257-270.

[2] Peerzada, M.N., Khan, P, Ahmad, K., Hassan, M.I. and Azam, A. (2018) Synthesis, Characterization and Biological Evaluation of Tertiary Sulfonamide Derivatives of Pyridyl-Indole Based Heteroaryl Chalcone as Potential Carbonic Anhydrase IX Inhibitors and Anticancer Agents. European Journal of Medicinal Chemistry, 155, 13-23. https://doi.org/10.1016/j.ejmech.2018.05.034

[3] Sudhakar, A. (2009) History of Cancer, Ancient and Modern Treatment Methods. Journal of Cancer Science and Therapy, 1, i-iv. https://doi.org/10.4172/1948-5956.100000e2

[4] Mohamed, S., Shaaban, M. and Heiba, H.R. (2012) Synthesis of New Thiazole Derivatives Bearing a Sulfonamide Moiety of Expected Anticancer and Radiosensitizing Activities. Cairo University, Cairo.

[5] Tony, L.B. (2017) Phototherapy in Cancer Prevention and Treatment. Cancer Prevention \& Current Research, 7, Article No. 00224.

https://doi.org/10.15406/jcpcr.2017.07.00224

[6] Ihmaid, S., Ahmed, H.E.A. and Zayed, M.F. (2018) The Design and Development of Potent Small Molecules as Anticancer Agents Targeting EGFR TK and Tubulin Polymerization. International Journal of Molecular Sciences, 19, Article No. 408. https://doi.org/10.3390/ijms19020408

[7] Abou El Ella, D.A., Ghorab, M.M., Noaman, E., Heiba, H.I. and Khalil, A.I. (2008) Molecular Modeling Study and Synthesis of Novel pyrrolo[2,3-d]pyrimidines and Pyrrolotriazolopyrimidines of Expected Antitumor and Radioprotective Activities. Bioorganic \& Medicinal Chemistry, 16, 2391-2402. https://doi.org/10.1016/j.bmc.2007.11.072

[8] El-Deeb, I., Bayoumi, M. and El-sherbeny, A.A.-A. (2010) Synthesis and Antitumor Evaluation of Novel Cyclic Arylsulfonylureas: ADME-T and Pharmacophore Prediction. European Journal of Medicinal Chemistry, 45, 2516-2530. https://doi.org/10.1016/j.ejmech.2010.02.038

[9] Lavanya, R. (2017) Sulphonamides: A Pharmaceutical Review. International Journal of Pharmaceutical Science Invention, 6, 1-3.

[10] Kaur, L., Arora, V., Arora, P. and Singh, M.P. (2018) A Review: Biological Significance of Sulfonamides. World Journal of Pharmacy and Pharmaceutical Sciences, 7, 413-422.

[11] Saeedi, M., Goli, F., Mahdavi, M., Dehghan, G., Faramarzi, M.A., Foroumadi, A., et 
al. (2014) Synthesis and Biological Investigation of Some Novel Sulfonamide and Amide Derivatives Containing Coumarin Moieties. Iranian Journal of Pharmaceutical Research, 13, 881-892.

[12] Kołaczek, A., Fusiarz, I., Lawecka, J. and Branowska, D. (2014) Biological Activity and Synthesis of Sulfonamide Derivatives: A Brief Review. Chemik, 68, 620-628.

[13] Behmadi, H., Saadati, S.M., Roshania, M. and Ghaemy, M. (2009) Synthesis of New Disulfonamides from Different Substituted Diamino Pyridines. Eclética Química Journal, 34, 27-31. https://doi.org/10.1590/S0100-46702009000300003

[14] Rehman, H., Qadir, A., Ali, Z., Nazir, S., Zahra, A. and Shahzady, T.G. (2017) Synthesis and Characterization of Novel Sulfonamides Derivatives and Their Antimicrobial, Antioxidant and Cytotoxicity Evaluation. Bulletin of the Chemical Society of Ethiopia, 31, 491-498. https://doi.org/10.4314/bcse.v31i3.13

[15] El-Henawy, A.A., Mohamed, S.I., Ibrahim, T.M.A. and El-Hag Ali, G.A.M. (2011) Synthesis of New Sulfonamide Scaffolds Acting as Anticancer Targeting CAII Protein. New York Science Journal, 4, 20-29.

[16] Rathish, I.G., Javed, K., Ahmad, S., Bano, S., Alam, M.S., Akhter, M., et al. (2012) Synthesis and Evaluation of Anticancer Activity of Some Novel 6-Aryl-2-( $p$-Sulfamylphenyl)-Pyridazin-3(2H)-Ones. European Journal of Medicinal Chemistry, 49, 304-309. https://doi.org/10.1016/j.ejmech.2012.01.026

[17] Sangande, F., Julianti, E. and Tjahjono, D.H. (2020) Ligand-Based Pharmacophore Modeling, Molecular Docking, and Molecular Dynamic Studies of Dual Tyrosine Kinase Inhibitor of EGFR. International Journal of Molecular Sciences, 21, Article No. 7779. https://doi.org/10.3390/ijms21207779

[18] Abuelizz, H.A., Marzouk, M., Ghabbour, H. and Al-Salahi, R. (2017) Synthesis and Anticancer Activity of New Quinazoline Derivatives. Saudi Pharmaceutical Journal, 25, 1047-1054. https://doi.org/10.1016/j.jsps.2017.04.022

[19] Bryan, M.C., Burdick, D.J., Chan, B.K., Chen, Y., Clausen, S., et al. (2016) Pyridones as Highly Selective, Noncovalent Inhibitors of T790M Double Mutants of EGFR. ACS Medicinal Chemistry Letters, 7, 100-104. https://doi.org/10.1021/acsmedchemlett.5b00428

[20] Matsushima, S., Ohtsuka, K., Ohnishi, H., Fujiwara, M., Nakamura, H., Morii, T., et al. (2014) V843I, a Lung Cancer Predisposing EGFR Mutation, Is Responsible for Resistance to EGFR Tyrosine Kinase Inhibitors. Journal of Thoracic Oncology, 9, 1377-1384. https://doi.org/10.1097/JTO.0000000000000241

[21] Singh, P. and Bast, F. (2014) In Silco Molecular Docking Study of Natural Compounds On Wild and Mutated CHEMISTRY in Silico Molecular Docking Study of Natural Compounds on Wild and Mutated Epidermal Growth Factor Receptor. Medicinal Chemistry Research, 23, 5074-5085.

https://doi.org/10.1007/s00044-014-1090-1

[22] Ghorab, M.M., Alsaid, M.S. and Nissan, Y.M. (2014) Synthesis and Molecular Docking of Some Novel Anticancer Sulfonamides Carrying a Biologically Active Pyrrole and pyrrolopyrimidine Moieties. Acta Poloniae Pharmaceutica-Drug Research, 71, 603-614.

[23] Zare, A., Hasaninejad, A., Moosavi-Zare, A.R., Parhami, A. and Khazaei, A. (2009) A Conversion of Carboxylic Acids to Amides under Microwave Irradiation. Asian Journal of Chemistry, 21, 1090-1096.

[24] Brahmachari, G., Laskar, S. and Sarkar, S. (2010) ChemInform Abstract: A Green Approach to Chemoselective N-Acetylation of Amines Using Catalytic amount of Zinc Acetate in Acetic Acid under Microwave Irradiation. ChemInform, 42, 1274-1281. 
https://doi.org/10.1002/chin.201103066

[25] Gangrade, D., Lad, S.D. and Mehta, A.L. (2015) Overview on Microwave Synthesis-Important Tool for Green Chemistry. International Journal of Research in Pharmaceutical Sciences, 5, 37-42.

[26] Stuart, B.H. (2005) Infrared Spectroscopy: Fundamentals and Applications. In: Kirk-Othmer Encyclopedia of Chemical Technology, John Wiley \& Sons, Inc., Hoboken. https://doi.org/10.1002/0471238961.0914061810151405.a01.pub2

[27] Balc1, M. (2005) Basic ${ }^{1} \mathrm{H}$ - and ${ }^{13} \mathrm{C}-\mathrm{NMR}$ Spectroscopy. Elsevier Science, Amsterdam. https://doi.org/10.1016/B978-0-444-51811-8.X5000-1 